\title{
DROGA NA SZCZYT I DROGA W OTCHLAŃ - KILKA UWAG O KARIERZE FLAWIUSZA STILICHONA
}

Przedstawiony artykuł nie jest absolutnie próbą nakreślenia choćby najskromniejszej biografii Flawiusza Stilichona (360/365 - 22/23 VIII 408) i ogranicza się jedynie do wskazania kilku spośród wielu jego działań i dokonań, które zdaniem autora niniejszego opracowania miały decydujący wpływ na zawrotną karierę i gwałtowny upadek tego wybitnego wodza i polityka z przełomu IV i V w. Mimo to warto na wstępie, osobom które nie są zbyt dobrze obeznane z historią późnego Cesarstwa Rzymskiego, przypomnieć najważniejsze fakty z życia bohatera tego artykułu.

Stilichon urodził się jako dziecko nieznanych nam z imion Wandala i Rzymianki. Można jedynie przypuszczać, że jego ojciec zajmował wysokie stanowisko oficerskie w armii rzymskiej ${ }^{1}$. Jeszcze mniej powiedzieć można o matce Stilichona, poza jednym - na pewno nie była branką uprowadzoną

* Prof. dr hab. Marek Wilczyński - Kierownik Katedry Historii Starożytnej w Instytucie Historii na Wydziale Humanistycznym Uniwersytetu Pedagogicznego im. Komisji Edukacji Narodowej w Krakowie; e-mail: wilczynski.m@wp.pl.

${ }^{1}$ Wydaje się, że nie do obronienia jest teza Herwiga Wolframa, usiłującego dowieść, że Stilichon urodził się jeszcze zanim jego ojciec wstąpił na służbę rzymską. Wiedeński znawca historii Gotów uważa, że specjalną zgodę na taki związek wyrazić musiał Julian Apostata (331/332 - 26 VI 363, cesarz od 3 XI 361) lub Konstancjusz II (7 VIII 317 - 3 XI 361, cesarz od 9 IX 337), jednak po pierwsze nie podaje niepodważalnych argumentów za tym, że narodziny Stilichona nastąpiły przed zaciagnięciem się jego ojca na służbę rzymską, a po drugie nie wyjaśnia czemu zgodę wyrazić musiał któryś z wymienionych cesarzy, skoro zakaz conubium między barbarzyńcami a Rzymianami jest późniejszy. Wydał go w edykcie z dnia 28 maja 373 r. cesarz Walentynian I (321 - 17 XI 375, cesarz od 26 II 364), por. CTh III 14, 1, ed. Th. Mommsen - P.M. Meyer: Theodosiani libri XVI cvm Constitvtionibvs Sirmondianis et leges novellae ad Theodosianvm pertinentes, vol. 1, pars 2: Textvs cvm apparatv, Berolini 1905, 155. Zatem jeżeli jako pierwszą przesłankę przyjmiemy datę urodzin Stilichona: ok. roku 360 według Hertwiga Wolframa (Das Reich und die Germanen. Zwischen Antike und Mittelalter, Berlin 1990, 146) i Iana Hughesa (Stilicho: The Vandal Who Saved Rome, Barnsley 2010, 14); lub rok 365 zdaniem Otto Seecka (Flavius Stilicho, RE III A/2 [2. Reihe] 2523); a jako drugą przesłankę przypuszczenie, że nie przyszedł on na świat przed formalnym związkiem swoich rodziców, to z prostego sylogizmu wynika, że małżeństwo nastąpiło przed formalnym zakazem conubium. Poza tym od samego początku wychowanie Stilichona wskazywało, że jego rodzice mogli zapewnić mu rozwój kariery u dworu, co byłoby łatwiejsze, gdyby nieznany nam z imienia Wandal już od dłuższego czasu zajmował jakieś stanowisko w armii cesarskiej, a nie ubiegał się o nie mozolnie dopiero po zawarciu małżeństwa. 
przez barbarzyńcę, a małżeństwo zawarła dobrowolnie na terenie imperium. Nie znamy niestety jej pochodzenia, choć istnieją próby dowodzenia, że pochodziła z uprzywilejowanych warstw społeczeństwa rzymskiego ${ }^{2}$. Zważywszy na dalszy szybki rozwój kariery Stilichona, trudno wykluczyć, że zasługi militarne i znajomości ojca w kręgach arystokracji wojskowej, a także być może w miarę dobry status społeczny matki, musiały stanowić dogodny punkt startowy dla przyszłego potężnego magistra militum. Kariera ta rozwijała się zapewne według przyjętego w tamtych czasach szablonu, a jej bieg bardzo lakonicznie opisano $\mathrm{w}$ inskrypcji ufundowanej ku czci Stilichona przez senat po stłumieniu buntu Gildona († 398) w Afryce ${ }^{3}$. Dodatkowym źródłem informacji o okresie młodości Stilichona są panegiryki Klaudiusza Klaudiana (ok. 370 - 404), choć jak zawsze w przypadku tego typu materiału źródłowego, konieczna jest daleko idąca ostrożność.

Stilichon zapewne już w wieku dziecięcym rozpoczął szkolenie w elitarnych jednostkach pałacowych, co było typowym początkiem kariery chłopca pochodzącego z późnorzymskiej arystokracji wojskowej. Przypuszczalnie zdobywał kompetencje wojskowe w którejś z pałacowych scholae ${ }^{4}$. Większość badaczy ostrożnie nie zajmuje stanowiska w sprawie młodości Stilichona, uważając za pierwszy uchwytny punkt jego życiorysu to ewentualny udział w poselstwie wysłanym przez Teodozjusza I Wielkiego (11 I 347 - 17 I 395,

${ }^{2}$ Ian Hughes (Stilicho, s. 14) uważa, że matka Stilichona musiała zajmować wystarczająco eminentną pozycję społeczną, by mimo barbarzyńskiego pochodzenia ojca zapewnić synowi odpowiednio wysoki punkt startu do kariery. Jednak i ta teoria ma słabe strony. Rodzi się bowiem pytanie, czy w połowie IV w., w czasach karier Newitty (357-363), Merobaudesa († 383 lub 388) i Arbogasta († 8 IX 394), rzeczywiście trzeba było „zacierać” ślady barbarzyńskiego pochodzenia ojca. Mimo wszystko stawiać należy chyba na wpływy posiadane przez ojca Stilichona, wpływy, które oczywiście pozwoliły mu na związek z Rzymianką z uprzywilejowanej warstwy społecznej i na kierowanie kształceniem wojskowym syna. Nie można też wykluczyć, że dobra pozycja dla życiowego startu Stylichona była wynikiem połączenia wpływów i znaczenia obojga jego rodziców. Jednak wobec braku jednoznacznego świadectwa źródeł stawiać można w tym względzie dowolne hipotezy.

${ }^{3}$ Por. O. Fiebiger - L. Schmidt, Inschriftensammlung zur Geschichte der Ostgermanen, Denkschriften der Kaiserlichen Akademie der Wissenschaften in Wien. Philosophisch-historische Klasse 60/3, Wien 1917, 23 (inskrypcja nr 21). Ten sam tekst w CIL VI/1, 1730, 1-13, ed. E. Bormann - G. Henzen: CIL, VI/1: Inscriptiones urbis Romae latinae, pars 1, Berolini 1876, 380 „Fl(avio) Stilichoni v(iro) c(larissimo). / Fl(avio) Stilichoni inlustrissimo viro / magistro equitum peditumque, / comiti domesticorum, tribuno praetoriano II et ab ineunte aetate per gradus claris / simae militiae ad columen gloriae / sempiternae et regiae adfinitatis evecto, / progenero divi Theodosi Augusti in omnibus bellis // adque victoriis et ab eo in adfinitatem / regiam cooptato itemque socero d(omini) n(ostri) / Honori Augusti, Africa consiliis eius I et provisione liberata, ex s(enatus) c(onsulto). Podobnych, choć nie identycznych, informacji dostarcza też inskrypcja publikowana w Fiebiger - Schmidt, Inschriftensammlung zur Geschichte der Ostgermanen, s. 26-27 (inskrypcja nr 26). Ten sam tekst w CIL VI/1, 1731, 1-24, ed. Bormann - Henzen, s. 380.

${ }^{4}$ Otto Seeck (Flavius Stilicho, RE III A/2 [2. Reihe] 2523) uważa, że wzmianka, iż Stilichon służył „ab ineunte aetate per gradus clarissimae militiae” (patrz inskrypcja w przypisie powyżej) wskazuje niekoniecznie na scholae i może też dotyczyć jednostek pałacowych takich jak protectores lub domestici. 
cesarz od 19 I 379) do Persji w roku $383^{5}$. Po powrocie z misji na Wschodzie Stilichon dostąpił pierwszego prawdziwie ważnego zaszczytu, kiedy cesarz Teodozjusz wydał za niego swoją bratanicę Serenę (384-408), którą wychowywał i traktował jak rodzoną córkę. Równocześnie awansował on do dworskiej godności koniuszego (comes sacri stabuli). Prawdopodobnie w dwa lata później następuje kolejny awans do stopnia comes domesticorum, co można uznać za pierwszy ważny krok do najwyższych szczebli kariery wojskowej ${ }^{6}$. W 391 r., w obliczu buntu Wizygotów pod wodzą Alaryka (ok. 370 - 410/411) i śmierci w walkach z barbarzyńcami magistra militum Promotusa $(\dagger 391)^{7}$, Stilichon przejął osierocone stanowisko poległego i energicznie rozprawił się z Wizygotami, otaczając buntowników i głodem zmuszając do ponownego uznania zasad foedus zawartego z Teodozjuszem I w roku $382^{8}$. Znaczenie tego sukcesu dla stabilizacji eminentnej pozycji Stilichona na dworze wielokrotnie podkreślał wspomniany już wyżej Klaudian ${ }^{9}$. Na najwyższe szczeble swojej kariery Stilichon wspiął się uczestnicząc w roku 394, u boku Teodozjusza Wielkiego, w wyprawie przeciw uzurpatorowi Eugeniuszowi († 6 IX 394), w zwycięskiej bitwie nad Frigidusem, a następnie umacniając władze domu teodozjańskiego w zachodniej części imperium. Gdy po niespodziewanej śmierci cesarza przejął opiekę nad jego następcą Honoriuszem (9 IX 384 - 15 VIII 423, cesarz od 17 I 395), a wraz z nią realną władzę nad zachodnim cesarstwem, osiągnął najwyższy punkt kariery politycznej i przez najbliższe 12 lat utrzymywał pozycję najpotężniejszego człowieka na rzymskim Zachodzie, a ambicjami sięgał dalej, pragnąc sprawować rządy także nad wschodnią

${ }^{5}$ Claudianus (De consulatu Stilichonis I 51-68, ed. T. Birt, MGH Auctores Antiquissimi X, Berolini 1892, 191) opisuje podjętą przez Stilichona, w młodzieńczym jeszcze wieku, wyprawę w charakterze eskorty pewnego poselstwa poprzez Tygrys i Eufrat aż do Babilonii i kraju Partów (oczywista poetycka archaizacja), gdzie m.in. mężnie ochraniał wysłanników cesarza przed dziką zwierzyną.

${ }^{6}$ Omówienie dyskusji nad tą datą oraz hipotez związanych z kolejnymi awansami z początkiem lat 90. IV w., por. M. Wilczyński, Germanie w stużbie zachodniorzymskiej w V w. n.e. Studium historyczno-prosopograficzne, Kraków 2001, 336-340 i nota 27. Wątpliwości nie ma I. Hughes (Stilicho, s. 21), który zakłada, że w roku 388 Stilichon jako comes domesticorum musiał towarzyszyć Teodozjuszowi Wielkiemu w wyprawie do Italii i brać udział w zwycięskich bitwach pod Siscia i Poetivio, mimo że, jak sam przyznaje, nie ma w źródłach z tego okresu nic na temat Stilichona.

${ }^{7}$ Por. Zosimus, Historia Nova IV 51, 1-3, ed. L. Mendelssohn, Lipsiae 1887, 208.

${ }^{8} \mathrm{Na}$ temat zmagań z Wizygotami na Bałkanach i udziału w nich Stilichona por. M. Wilczyński, Wizygoci w rejonie Bałkanów w teorii i praktyce politycznej dworów późnego cesarstwa rzymskiego, VoxP 36 (2016) t. 66, 301-325.

${ }^{9}$ Por. Claudianus, De consulatu Stilichonis I 94-96, MGH Auctores Antiquissimi X 192; tenże, In Rufinum I 308-335, ed. T. Birt, MGH Auctores Antiquissimi X 30-31; tenże, De VI consulatu Honorii 105-108, ed. T. Birt, MGH Auctores Antiquissimi X 239; tenże, De bello Pollentino 525, ed. T. Birt, MGH Auctores Antiquissimi X 278; Laus Serenae 207-209, ed. T. Birt: MGH Auctores Antiquissimi X 327. Na pewno także to wydarzenie miał na myśli Orozjusz (Historiae adversum paganos VII 37, 2, ed. C. Zangemeister: Orosius, Historiae adversum paganos. Liber apologeticus, CSEL 5, Vindobonae 1882 [reprint: Hildesheim 1967], 537, 5-12) oskarżając Stilichona, że wielokrotnie pokonywał Alaryka i jego Gotów, by go również wielokrotnie bezkarnie wypuszczać z matni. 
częścią cesarstwa. Jednak po tym tak spektakularnym okresie zasiadania na szczytach władzy, w roku 408 nastapił gwałtowny upadek Stilichona w otchłań cesarskiej niełaski, skutkiem czego został on opuszczony przez swych dotychczasowych sojuszników politycznych, a następnie otrzymał wyrok kary śmierci zakończony egzekucją.

Zastanawiając się nad fenomenem politycznych sukcesów Stilichona można wskazać cztery podstawowe filary, na których oparł i przez stosunkowo długi czas utrzymał najwyższą pozycję w cesarstwie zachodniorzymskim na przełomie IV i V w. Trudno przy tym rozstrzygnąć, który z nich miał większe znaczenie, ponieważ - jak w każdej konstrukcji politycznej, tak i w tej - gwarantem stabilności była równowaga pomiędzy wszystkimi punktami podparcia, którymi bez wątpienia były: 1. Umiejętna budowa związków pokrewieństwa i zależności pomiędzy Stilichonem a domem Teodozjańskim; 2. Skuteczna organizacja armii i jej związanie z osobą magistra militum oraz sukcesy militarne, gwarantujące zachodniemu cesarstwu względną stabilność granic i poczucie bezpieczeństwa; 3. Rozsądna polityka prowadzona wobec elit senatorskich Italii oraz umiarkowana, choć jednoznacznie prochrześcijańska polityka religijna; 4. Zrozumienie niemożności całkowitego zniszczenia zagrażających imperium barbarzyńców i kontynuacja Teodozjańskiej polityki równowagi pomiędzy odpieraniem barbarzyńców, a ich wykorzystywaniem dla sukcesów polityki imperialnej.

Aby w pełni zrozumieć powody wyniesienia i upadku Stilichona należy krótko przeanalizować każdy z wymienionych aspektów zarówno pod kątem jego wieloletnich sukcesów, jak i nagłego upadku.

Ad. 1. Jak już wspomniano powyżej, jednym z pierwszych znaczących kroków w karierze Stilichona było małżeństwo z Sereną, bratanicą cesarza Teodozjusza I Wielkiego. Już samo powinowactwo z cesarzem stawiało młodego wówczas Stilichona wśród dworskiej elity, a z biegiem czasu związki z rodziną cesarską nabrały znaczenia politycznego. Nagła śmierć Teodozjusza I (17 I 395) dała Stilichonowi możliwość zgłoszenia pretensji do opieki nad synami zmarłego, czyli nad niezdolnym de facto do sprawowania władzy Arkadiuszem (ok. 377 - 1 V 408, cesarz od 17 I 395) i nad nieletnim wówczas jeszcze Honoriuszem ${ }^{10}$. Opiekę tę miał mu podobno zlecić umierający Teodozjusz, jednak jedynymi świadkami tego wydarzenia byli sam Stilichon i biskup Mediolanu św. Ambroży (ok. 339 - 4 IV 397). Ten ostatni zachował daleko idącą powściagliwość $\mathrm{w}$ relacji ${ }^{11}$. Stilichon natomiast za pośrednictwem Klau-

${ }^{10}$ Por. K. Zakrzewski, Rzady i opozycja za cesarza Arkadiusza, Polska Akademia Umiejętności. Rozprawy Wydziału Historyczno-Filozoficznego II/40-2, Kraków 1927, 1. Wyrażona wtedy opinia wybitnego polskiego bizantynisty zachowuje stale swoją aktualność.

${ }^{11}$ Por. Ambrosius, De obitu Theodosii 5 i 6-8, PL 16 1387B-1389B. Biskup wzywał dostojników wojskowych i świeckich do opieki nad synami zmarłego, podkreślając z mocą, że to winni są Teodozjuszowi, ale nie wymienił z imienia, ani tym bardziej nie wyróżnił Stilichona. Por. też 
diana głosił wszem i wobec, że wolą zmarłego było, aby to on właśnie otoczył opieką obydwóch młodych cesarzy ${ }^{12}$. Podobne, choć mniej jednoznaczne informacje przekazali Olimpiodor (ok. 380 - ok. 425) i Zosimos (ok. 425 - ok. $518)^{13}$. Jak wiadomo, mimo podejmowanych kilkakrotnie prób nie udało się zrealizować tego optymalnego planu, dającego Stilichonowi władzę nad całością imperium. Jednak umiejętna polityka matrymonialna zapewniła mu silną pozycję u boku Honoriusza. W 398 r., świeżo opromieniony sławą pogromcy powstania Gildona w Afryce, lub może jeszcze w trakcie działań wojennych ${ }^{14}$, Stilichon wydał swoją starszą córkę Marię († 407/408) za cesarza Zachodu ${ }^{15}$.

T. Janßen, Das weströmische Reich vom Tode des Theodosius bis zur Ermordung Stilichos (395408), Marburg 2004, 29-32; Hughes, Stilicho, s. 30; M.A. McEvoy, Child Emperor Rule in the Late Roman West AD 367-455, Oxford 2013, 144-149.

${ }^{12} \mathrm{Z}$ okazji rozpoczęcia 1 I 396 r. trzeciego konsulatu Honoriusza Klaudian wygłosił panegiryk, w którym w usta Teodozjusza wkładał jednoznaczne polecenia dla Stilichona: „tu curis succede meis, tu pignora solus / nostra fove: geminos dextra tu protege fratres" (Claudianus, De III consulatu Honorii 152-153, ed. T. Birt, MGH Auctores Antiquissimi X 146). Wagę poetyckiej wizji Klaudiana podkreślał Johannes Straub, (Parens principum. Stilichos Reichspolitik und das Testament des Kaisers Theodosius, „La nouvelle Clio” 4:1952, 101), wskazując, że słowa te poeta mógł wypowiadać publicznie w czasie oficjalnej uroczystości dworskiej. Później w inwektywie przeciw Rufinowi (ok. 335 - 27 XI 395) Klaudian ponownie jednoznacznie nawiązywał do powierzenia opieki nad obydwoma synami Teodozjusza Wielkiego, por. Claudianus, In Rufinum II 4-6, MGH Auctores Antiquissimi X 34: „Iamque tuis Stilicho Romana potentia curis / Et rerum comissus apex, tibi credita fratrum / Utraque maiestas geminaeque exercitus aulae”. Zdecydowanie przeciwko ewentualnej możliwości objęcia przez Stilichona tutela także Arkadiusza wypowiedział się ostatnio Rene Pfeilschifter (Die Spätantike. Der eine Gott und die vielen Herrscher, München 2014, 128). W dyskusji na temat sporu o tutele oraz na temat konfliktu z Arkadiuszem i jego dworem głos zabierali między innymi John F. Drinkwater (Constantine III (407-411) and Jovinus (411-413), „Britania” 29:1998, 270-271) i Richard P.C. Hanson (The Reaction of the Church to the Collapse of the Western Roman Empire in the Fifth Century, VigCh 26:1972, 272-273).

${ }^{13}$ Por. Olympiodorus, Historiarum librorum XXII fragmenta 1, ed. R.C. Blockley, w: The Fragmentary Classicising Historians of the Later Roman Empire. Eunapius, Olympiodorus, Priscus and Malchus, vol. 2: Text, Translation and Historiographical Notes, ARCA Classical and Medieval

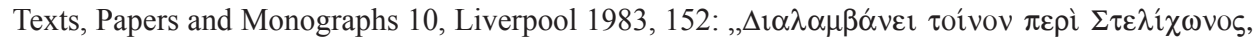

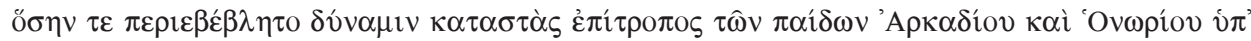

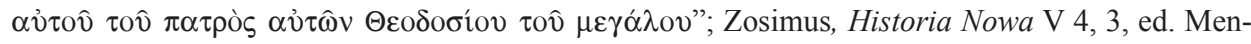
delssohn, s. 220-221: „,̌̉̇

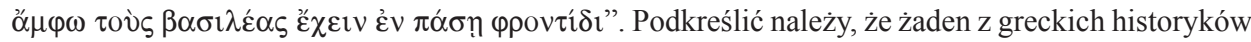
nie podaje tej wiadomości od siebie, ale podkreślając, że taka była opinia Stilichona.

${ }^{14}$ Meaghan McEvoy (Child Emperor Rule in the Late Roman West AD 367-455, s. 160) uważa, że zaślubiny nastapiły przed nadejściem wiadomości o ostatecznym zwycięstwie w Afryce.

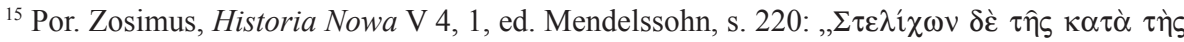

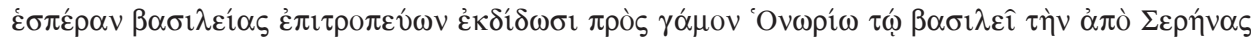

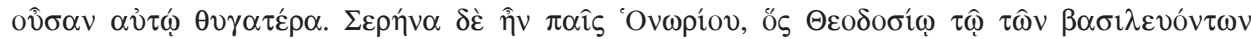
$\pi \alpha \tau p \grave{~ \gamma \varepsilon ́ \gamma o v \varepsilon v ~ \alpha ̉ \delta \varepsilon \lambda \varphi o ́ s " ; ~ J o r d a n e s, ~ G e t i c a ~ 154, ~ e d . ~ T h . ~ M o m m s e n: ~ M G H ~ A u c t o r e s ~ A n t i q u i s s i m i ~}$ V/1, Berolini 1882, 98: „nam utramque eius filiam, id est Mariam et Thermantiam, sibi princeps unam post unam consocians utramque virginem et intactam deus ab hac luce vocavit"; Marcellinus Comes, Chronica a. 408, 1, ed. Th. Mommsen: MGH Auctores Antiquissimi XI, Berolini 1894, 
Małżeństwo 12-letniej Marii i 14-letniego Honoriusza zawarto w momencie, gdy cesarz niebezpiecznie zbliżał się do wieku, w którym mógł próbować się uniezależnić, a związki powinowactwa, realizujące, jak twierdził Klaudian, dalekosiężne plany samego Teodozjusza ${ }^{16}$ uprawniały tym bardziej Stilichona do dalszej tuteli nad zięciem i córką. Po pierwszym sukcesie matrymonialnym Stilichon planował być może następny mariaż, który tym razem połączyć miał jego własnego syna, Eucheriusza (389-408), z przyrodnią siostrą Arkadiusza i Honoriusza Gallą Placydią (ok. 390 - 27 XI 450). Idąc za sugestiami Klaudiana można przypuścić, że plany takiego związku istniały już ok. 400 r., ponieważ aluzje na ten temat zawiera panegiryk na konsulat Stilichona ${ }^{17}$. Natomiast po jego upadku powtarzano oskarżenia o chęć osadzenia Eucheriusza na tronie. Jednak jeżeli rzeczywiście planowano zaręczyny z Gallą Placydia, to raczej jako drugie ogniwo powinowactwa $\mathrm{z}$ domem cesarskim, a nie jako wstęp do zamachu stanu. Po bezdzietnej śmierci Marii w 407 lub 408 r. Stilichonowi udało się jeszcze zaaranżować małżeństwo młodszej córki, Thermantii $(\dagger 415)$, z Honoriuszem, jednak ten związek nie przyniósł spodziewanego polepszenia psujących się już wtedy stosunków między cesarzem a jego podwójnym teściem. Na marginesie można wspomnieć też mniej znaczące małżeństwo siostry Stilichona z Batanariuszem († 408), który był komesem Afryki. Znaczenie zbożodajnej diecezji było tak duże, że obsadzenie jej przez szwagra Stilichona mogło mieć dla magistra militum znaczenie strategiczne ${ }^{18}$.

Ad. 2. W momencie przejęcia opieki nad Honoriuszem Stilichon był w trakcie szeroko zakrojonych działań, mających przywrócić dyscyplinę i lojalność wobec domu Teodozjańskiego w szeregach armii Zachodu, niedawno jeszcze walczącej po stronie uzurpatora Eugeniusza. Wprawdzie po zwycięstwie nad rzeką Frigidus na Zachodzie pozostawał wschodniorzymski korpus, przybyły z cesarzem i podlegający rozkazom Stilichona, jednak wiadomo było, że jest to stan tymczasowy ${ }^{19}$. Jeszcze za życia Teodozjusza I starano

69: „Stilico, comes, cuius duae filiae Maria et Thermantia singulare uxores Honorii principis fuere, utraque tamen virgo defuncta".

${ }^{16}$ Meaghan McEvoy (Child Emperor Rule in the Late Roman West AD 367-455, s. 160, nota 54) zwraca uwagę, że w poetyckim ujęciu Klaudiana animatorem związku miał być sam zmarły przed trzema laty Teodozjusz.

${ }^{17}$ Por. Claudianus, De consulatu Stilichonis II 256-361, MGH Autores Antiquissimi X 212-215.

${ }^{18}$ Niewiele o nim wiadomo. Zosimos (Historia Nova V 37, 6, ed. Mendelssohn, s. 265) wspomina o jego zamordowaniu po upadku Stilichona. Jako komes Afryki jest wymieniony pierwszy raz 13 VI 401 r. (CTh IX 42, 18, ed. Mommsen - Meyer, vol. 1, pars 2, s. 515). Wspomina też o nim przez św. Augustyna (13 XI 354 - 28 VIII 430). W świetle jego relacji komes Afryki miał być zainteresowany nauką i w obecności Sewera, biskupa Milewy, przeprowadził ciekawy eksperyment z magnesem; Augustinus, De civitate Dei XXI 4, rec. E. Hoffmann, CSEL 40/2, Pragae - Vindobonae-Lipsiae 1900, 520, 13-21.

${ }^{19}$ Bardzo szybko, bo już w czasie pierwszej wyprawy Stilichona do Illyricum przeciw Alarykowi, Arkadiusz zażądał zwrotu jednostek wschodnich za namową konkurującego ze Stilichonem pre- 
się pozyskać zaufanie jednostek armii zachodniej, równocześnie dyskretnie wymieniając wyższe dowództwo. Dotychczasowym środowiskiem, z którego pochodzili wysokiej rangi dowódcy Zachodu była tak zwana „,klika frankońska"20. Można bowiem zauważyć, że w 2 poł. IV w. najwyższe stopnie wojskowe piastowane są przez oficerów pochodzenia frankońskiego, których najwybitniejszym przedstawicielem był magister militum Arbogast - zbrojne ramię i zapewne także mózg uzurpacji Eugeniusza. W tym kontekście należy także wymienić ojca i wuja Arbogasta, czyli Bautona († ok. 388) i Richomerusa $(\dagger 393)^{21}$. Kolejnym przedstawicielem „kliki frankońskiej” był zapewne $m a-$ gister militum Merobaudes, który zapewnił sobie silną pozycję u boku cesarza Gracjana (18 IV 359 - 25 VIII 383, cesarz od 17 XI 375). Jeżeli założymy, że Bauto był ojcem Arbogasta, być może mamy do czynienia z praktycznym przechodzeniem dowództwa naczelnego w linii rodzinnej ${ }^{22}$. Ten stan rzeczy musiał ulec zmianie i Stilichon doprowadził do obsadzenia stanowisk dowódczych swoimi zaufanymi ludźmi takimi jak Sarus $(† 412)$, Sigiswult $(† 449)$, Saul († 6 IV 402), czy Uldin († przed 412), dbając jednak przy tym, aby „,kliki frankońskiej” nie zastąpiła „klika gocko-huńska”. Przeprowadził także szereg refom mających na celu wzmocnienie stanu liczebnego wojsk Zachodu, ułatwienie zaciagu, powstrzymanie dezercji ${ }^{23}$ oraz ukrócenie nadużyć władz

fekta Rufina (Claudianus, In Rufinum II, 174-175 i 228-247, MGH Auctores Antiquissimi X 42-43). Na temat znaczenia kontyngentu wschodniego w okresie bezpośrednio po przybyciu Teodozjusza i Stilichona do Italii, por. Pfeilschifter, Die Spätantike. Der eine Gott und die vielen Herrscher, s. 128.

${ }^{20}$ Autorem tego określenia jest László Várady (Das letzte Jahrhundert Pannoniens. 376-476, Amsterdam 1969, 42-45). W literaturze przedmiotu XXI w. ponownie do tego tematu powrócił Tido Janßen (Das weströmische Reich vom Tode des Theodosius bis zur Ermordung Stilichos, s. 7).

${ }^{21}$ Trudno negować powiązania rodzinne osób zaliczanych do „kliki frankońskiej”. Stosunki pokrewieństwa między nimi poświadcza Jan z Antiochii (VI/VII w.) - Ioannes Antiochenus, Fragmenta 212, 1, rec., Anglice vertit, indicibus instruxit S. Mariev, CFHB Series Berolinensis 47, Berolini

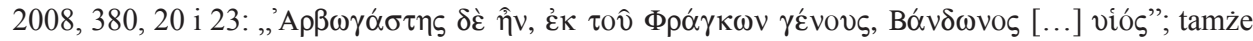

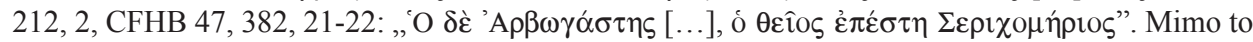
Arnold H.M. Jones (The Prosopography of the Later Roman Empire: 260-395, Cambridge 1971, 97) neguje pokrewieństwo Arbogasta z Bautonem i Richomerem.

${ }^{22} \mathrm{O}$ czym przekonuje Tido Janßen (Das weströmische Reich vom Tode des Theodosius bis zur Ermordung Stilichos, s. 7, nota 22).

${ }^{23}$ Przykładem może być prowadzona w Galii akcja rekrutacyjna, mająca na celu wzmocnienie etatu armii zachodniej, obejmująca barbarzyńców i kolonów z prowincji. Ian Hughes (Stilicho, s. 117) i Tido Janßen (Das weströmische Reich vom Tode des Theodosius bis zur Ermordung Stilichos, s. 64) skłonni są dopatrywać się w dość licznych (21) jednostkach noszących nazwę Honoriani, które wymienia Notitia ignitatum na etacie Zachodu, właśnie tych nowo sformowanych przez Stilichona jednostek. Aktualnie uważa się, że był to znaczący sukces magistra militum, ale wcześniejsza literatura (J.M. O'Flynn, Generalissimos of the Western Empire, Edmonton 1983, 3335, a za nim A. Demandt, Die Spätantike. Römische Geschichte von Diocletian bis Justinian 284565 n. Chr., München - Nördlingen 1989, 141) negowała wartość bojową poczynionych zaciagów, argumentując, że zawodność owych nowych jednostek nie pozwoliła Stilichonowi na ostateczną rozprawę z Alarykiem. Wydaje się jednak, że zanim przyjmiemy taką argumentację musimy zadać 
wojskowych wobec ludności cywilnej ${ }^{24}$. Pod koniec swojej kariery Stilichon usiłował także budować nową armię z zaciągu italskiego, która wprawdzie nie zdołała wykazać pod jego dowództwem swojej wartości bojowej, ale odegrała znaczącą rolę w spisku przeciwko niemu. Widomym dla mieszkańców zachodniego cesarstwa znakiem powodzenia Stilichona na polu militarnym były na pewno udane operacje wojskowe, zapewniające prowincjom zachodnim ochronę i bezpieczeństwo na okres dekady. Już w pierwszym roku zarządzania Zachodem wykazał się on nie tylko energia, ale i wolą niesienia pomocy prowincjom bałkańskim, grabionym przez Wizygotów Alaryka, którego podobnie jak w roku 391 otoczył, tym razem u stóp Olimpu. Żądanie zwrotu wojsk wschodniorzymskich Arkadiuszowi, któremu Stilichon się podporządkował, zmusiło go do wypuszczenia Alaryka z pułapki, jednak w 397 r. wojska Zachodu ponownie pojawiły się na Peloponezie, by ponownie zablokować króla Wizygotów w górach Foloe ${ }^{25}$. Tym razem inspirowane z Konstantynopola powstanie Gildona w Afryce spowodowało, że Alaryk raz jeszcze uszedł bez narzucenia mu warunków pokojowych po myśli Stilichona. Opiekun Honoriusza musiał spiesznie wycofać armię z Peloponezu i pilnie rozpocząć operacje militarne przeciwko afrykańskim buntownikom. Osobiście nie dowodził, ale zaplanowane przez niego działania zakończyły się pełnym sukcesem i ponownym podporządkowaniem Afryki Honoriuszowi w 398 r. Po dwóch latach spokoju, w roku 401 Stilichon powstrzymał najazdy barbarzyńców (Wandalów Asdingów) na pograniczu alpejskim ${ }^{26} \mathrm{i}$ jeszcze w tym samym roku stawił czo-

sobie ważkie pytanie, a mianowicie czy Stilichon w ogóle chciał ostatecznie rozprawić się z Alarykiem? Wiele wskazuje na to, że nigdy takiego zamiaru nie miał.

${ }^{24}$ Jako przykład dbałości Stilichona o dobre stosunki pomiędzy armią a ludnością prowincji można wymienić rozporządzenia, ograniczające możliwość dowolnego i bezzasadnego nakładania na ludność cywilną ciężarów aprowizacyjnych i robót publicznych przez lokalnych dowódców wojskowych (CTh VII 4, 26, ed. Mommsen - Meyer, vol. 1, pars 2, s. 257; tamże XI 7, 16, ed. Mommsen - Meyer, vol. 1, pars 2, s. 589). Równocześnie Stilichon nakazywał racjonalne gospodarowanie zasobami żywności na terenach stacjonowania wojsk i regularne zaspokajanie potrzeb aprowizacyjnych wojsk przez lokalną ludność i urzędy (CTh XI 5, 1, ed. Mommsen - Meyer, vol. 1, pars 2, s. 583-584; tamże XI 7, 16, ed. Mommsen - Meyer, vol. 1, pars 2, s. 589).

${ }^{25}$ Terytoria na Półwyspie Bałkańskim, najechane przez Wizygotów, leżały co prawda w rejonie podlegającym Konstantynopolowi, ale militarna aktywność Stilichona została pozytywnie oceniona nawet przez niechętnego mu Eunapiosa (347/349 - po 414), który przyznał, że Stilichon w przeciwieństwie do Rufina nie śledził bezczynnie łupienia Grecji przez barbarzyńców, ale udzielił jej mieszkańcom pomocy i powstrzymał wroga; por Eunapius Sardianus, Fragmenta historica IX 64, 1,

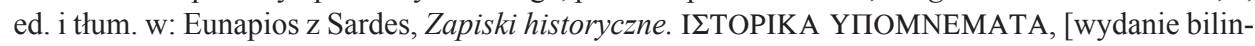
gwiczne], przekład, wstęp i objaśnienia A. Pająkowska-Bouallegui, Christianitas Antiqua 5, Gdańsk

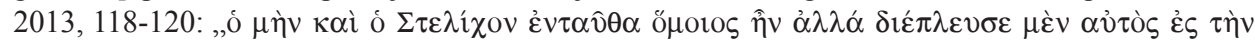

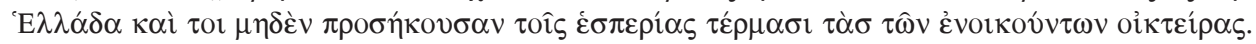

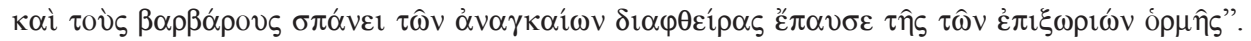

${ }^{26}$ Por. Claudianus, De bello Pollentino 279-288, MGH Auctores Antiquissimi X 269-270; tamże 414-415, MGH Auctores Antiquissimi X 274. Zob. Wolfram, Das Reich und die Germanen, s. 153; tenże, Die Goten. Von den Anfängen bis zur Mitte des sechsten Jahrhunderts. Entwurf einer 
ło najazdowi Wizygotów Alaryka, którym w Wielkanoc roku następnego zadał dotkliwą klęskę pod Polentią i zmusił do wycofania się na tereny Macedonii ${ }^{27}$. Za ostatni sukces militarny Stilichona uznać należy uratowanie Italii przed najazdem Radagaisa († 23 VIII 406), którego klęskę spowodowała umiejętna taktyka Stilichona, prowadząca do podziału sił przeciwnika na mniejsze kolumny marszowe i rozprawienia się z każdą z nich osobno ${ }^{28}$. Wziętymi do

historischen Ethnographie, München - Wien 1990³, 158; A. Schwarcz, Reichsangehörige Personen gotischer Herkunft. Prosopographische Studien, Wien 1984 (maszynopis), 181; M. Wilczyński, Zagraniczna i wewnętrzna polityka afrykańskiego państwa Wandalów, Kraków 1994, 14-15; tenże, Gejzeryk i ,czwarta wojna punicka”, Oświęcim 2016, 37; Janßen, Das weströmische Reich vom Tode des Theodosius bis zur Ermordung Stilichos, s. 132-134; Hughes, Stilicho, s. 135-136; H. Castritius, Die Vandalen. Etappen einer Spurensuche, Stuttgart 2007, 46-47; R. Steinacher, Die Vandalen. Aufstieg und Fall eines Barbarenreichs, Stuttgart 2016, 39. Wszyscy wyżej wymienieni autorzy, opierając się na podanym świadectwie Klaudiana, przyjmują, że Stilichon pokonał Wandalów przed atakiem Alaryka, natomiast Jerzy Strzelczyk (Wandalowie i ich afrykańskie państwo, Warszawa 2005, 80) uważa, że wydarzenia te mogły się rozegrać paralelnie i Wandalowie zostali pokonani w roku 402, przez lokalne siły rzymskie, a nie osobiście przez magistra militum.

${ }^{27}$ Por. Orosius, Historiae adversum paganos VII 37, 2, CSEL 5, 537, 6-10; Claudianus, De VI consulatu Honorii 127-132, MGH Auctores Antiquissimi X 240; tamże 202-203, MGH Auctores Antiquissimi X 242; tamże 281-316, MGH Auctores Antiquissimi X 245-246; tenże, De bello Pollentino 580-597, MGH Auctores Antiquissimi X 280-281; Prosper, Chronica, 1222, a. 402, ed. M. Becker - J.M. Mötter, w: Prosper Tiro, Chronik. [Anonymus], Laterculus regum Vandalorum et Alanorum, Kleine und Fragmentarische Historiker der Spätantike II/G 5-6, Paderborn 2016, 80; Cassiodorus, Chronica 1172, a. 402, ed. Th. Mommsen, MGH Auctores Antiquissimi XI 154; Jordanes Getica 154, MGH Auctores Antiquissimi V/1 98. Por też E. Demougeot, De l'unité à la division de l'empire romain: 395-410, Paris 1951, 278-280; A. Cameron, Claudian. Poetry and Propaganda at the Court of Honorius, Oxford 1970, 184, nota 3; O.J. Maenchen-Helfen, Die Welt der Hunnen. Eine Analyse ihrer historischen Dimension, deutschsprachige Ausgabe besorgt von R. Göbl, Wien 1978, 49, nota 258; Schwarcz, Reichsangehörige Personen gotischer Herkunft, s. 184; Wolfram, Die Goten, s. 160; Wilczyński, Germanie w stużbie zachodniorzymskiej w V w. n.e., s. 137-139 i 360-362; Janßen, Das weströmische Reich vom Tode des Theodosius bis zur Ermordung Stilichos, s. 134-142; G. Kampers, Geschichte der Westgoten, Padeborn - München - Wien - Zürich 2008, 102; Hughes, Stilicho, s. 137-149; McEvoy, Child Emperor Rule in the Late Roman West AD 367455, s. 174-175.

${ }^{28}$ Por. Zosimus, Historia Nova V 26, 3-4, ed. Mendelssohn, s. 249; Orosius, Historiae adversum paganos VII 37, 5, CSEL 5, 538, 1 - 542, 15. Por. L. Schmidt, Die Ostgermanen, München 1941, 265-267; S. Mazzarino, Stilicone. La crisi imperiale dopo Teodosio, Studi pubblicati dal Reale Istituto Italiano per la Storia Antica 3, Roma 1942, 278-280; E. Nischer-Falkenhof, Stilicho, Wien 1947, 125-127; Demougeot, De l'unité à la division de l'empire romain: 395-410, s. 354-356; J. Strzelczyk, Goci. Rzeczywistość i legenda, Warszawa 1984, 186; Wolfram, Die Goten, s. 175; I.N. Wood, The Barbarian Invasions and First Settlements, w: The Cambridge Ancient History, vol. 13: The Late Empire, AD 337-425, ed. A. Cameron - P. Garnsey, Cambridge 1998, 518-519; Wilczyński, Germanie w stużbie zachodniorzymskiej w V w. n.e., s. 367-370; Janßen, Das weströmische Reich vom Tode des Theodosius bis zur Ermordung Stilichos, s. 187-194; S. Mitchell, A History of the Later Roman Empire (AD 284 - 641), Malden 2007, 199; G. Halsall, Barbarian Migrations and the Roman West, Cambridge 2007, 206-210; P. Heather, Upadek Cesarstwa Rzymskiego, thum. J. Szczepański, Poznań 2006, 230-231; T. Stickler, Die Hunnen, München 2007, 55; Hughes, Stilicho, s. 162; McEvoy, Child Emperor Rule in the Late Roman West AD 367-455, s. 174; Ch. Kelly, 
niewoli najlepszymi wojownikami pokonanego Radagaisa Stilichon przezornie wzmocnił szeregi własnej armii ${ }^{29}$. Możliwe, że Stilichon nie należał do wodzów genialnych, ale do roku 406 był dowódcą skutecznym i gwarantował zachodniemu cesarstwu bezpieczeństwo granic, a w razie ich naruszenia potrafił z powodzeniem powstrzymać agresję. Wzmacniało to jego pozycję u dworu, wśród arystokracji senatorskiej i konserwowało obraz opatrznościowego obrońcy wśród ludu. Dopiero inwazja barbarzyńców, głównie Wandalów, Swebów i Alanów, na Galię w feralną, ostatnią noc 406 r. podważyła opinię o geniuszu strategicznym i militarnym Stilichona.

Ad. 3. $Z$ dużym prawdopodobieństwem założyć można, że elity senatorskie Italii i Wiecznego Miasta z nieufnością obserwowały poczynania Stilichona, który jako homo novus przybyły ze Wschodu na pewno nie budził ich zaufania. Wśród propogańskich kręgów senatorów mógł być postrzegany jeszcze bardziej negatywnie, jako powinowaty i bliski współpracownik pogromcy pogaństwa, Teodozjusza I Wielkiego. Mimo, że w okresie późnego cesarstwa arystokrację senatorską odsunięto od wpływu na armię, to jednak administracja cywilna w dużej mierze czerpała kadry z tej właśnie warstwy. Pozyskanie przychylności elity społeczeństwa zachodniorzymskiego było konieczne, by rządzić u boku Honoriusza, czasami nawet wykorzystując senat jako narzędzie nacisku na cesarza. Stilichon musiał balansować pomiędzy dochowywaniem wierności Teodozjańskiej polityce religijnej, a okazywaniem empatii pokonanej partii pogańskiej, mającej nadal sporo zwolenników w senacie $^{30}$. Zręcznie ukazywał swoją bezkompromisowość poza Italią, na przykład w Afryce, trzymanej żelazną ręką po upadku buntu Gildona. Działający tam z rozkazu rządu cesarskiego (a więc Stilichona) komesowie Gaudencjusz

Neither Conquest nor Settlement: Attila's Empire and ist Impact, w: The Age of Attila, ed. M. Maas, Cambridge 2015, 197; E.A. Thompson, Hunowie, opr. P. Heather, thum. B. Malarecka, Warszawa 2015, 33; J.W.P. Wijnendaele, Stilicho, Radagaissus, and the So-Called „Battie of Faesulae” (406 CE), ,Journal of Late Antiquity” 9 (2016) 268.

${ }^{29}$ Por. Olympiodorus, Historiarum librorum XXII fragmenta 9, ed. Blockley, s. 162: „"O $\tau \imath \tau \hat{\omega} \mathrm{v}$

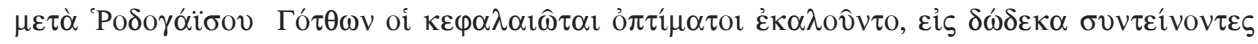

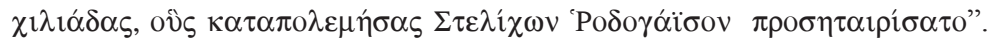

${ }^{30} \mathrm{~W}$ adresowanych do Apollodora, komesa Afryki, zarządzeniach widoczna jest zdecydowana wola działań na rzecz likwidacji miejsc kultu pogańskiego, co miało na celu uniemożliwienie odbywania zgromadzeń i obrzędów pogańskich, przy czym dopuszczano jednocześnie innego rodzaju zgromadzenia, por. CTh XVI 10, 17-18, ed. Mommsen - Meyer, vol. 1, pars 2, s. 902. Podobnie, a nawet jeszcze ostrzej sprawę stawiano w rozkazie przesłanym Eutychianowi, prefektowi pretorium (CTh XVI 10, 16, ed. Mommsen - Meyer, vol. 1, pars 2, s. 902: „Si qua in agris templa sunt, sine turba ac tumultu diruantur. His enim deiectis atque omnis supestitioni materia consumetur"). Należy jednak zwrócić uwagę, że edykt wydany w Damaszku 10 VII 399 r., a skierowany do Eutychiana, nie był na pewno w żaden sposób inspirowany przez Stilichona ani też z nim konsultowany. Przeciwnie, jest to dokument wydany przez dwór wschodni, który w tym czasie był w ostrym konflikcie ze Stilichonem. Natomiast polecenia kierowane do Apollodora, który podlegał cesarzowi Zachodu (a więc Stilichonowi), są znacznie bardziej liberalne. 
i Jowinus zniszczyli w roku 399 szereg miejsc kultu pogańskiego ${ }^{31}$. Jednak nawet rozkazując bezwzględne usuwanie pozostałości pogaństwa Stilichon nie dopuszczał do bezmyślnych zniszczeń i jeżeli byłe miejsca kultu pogańskiego służyły lokalnej społeczności jako miejsca użyteczności publicznej, zgromadzeń, obchodów, czy rozrywek nie związanych z kultem pogańskim i składaniem ofiar pozwalano na ich zachowanie, a nawet zabraniano ich dewastacji ${ }^{32}$. Gorliwość chrześcijańską rządca Zachodu starał się wykazać raczej na polu zwalczania herezji, co z kolei przed chrześcijańską partią w senacie dawało mu mandat gorliwego chrześcijanina. Ostrze prześladowań kierowano w stronę manichejczyków, donatystów, bądź pryscylian ${ }^{33}$. Pięknym gestem i kolejnym ukłonem Stilichona może nie tyle wobec pogaństwa, co wobec starorzymskiej tradycji, było ponowne umieszczenie w senacie posagu bogini Victorii ${ }^{34}$. Nie można rozstrzygnąć, czy przeciwnicy Stilichona oskarżający w 408 r. jego syna, Eucheriusza, o sympatie propogańskie mieli rację ${ }^{35}$, jednak nawet jeżeli w pomówieniach tych są okruchy prawdy, to i tak w pierwszym

${ }^{31}$ Działania i gorliwość władz zasłużyły na pochwałę św. Augustyna, por. Augustinus, De civitate Dei XVIII 54, CSEL 40/2, 361, 17-25: „Porro sequenti anno, consule Mallio Theodoro, quando iam secundum illud oraculum daemonum aut figmentum hominum nulla esse debuit religio Christiana, quid per alias terrarum partes forsitan factum sit, non fuit necesse perquirere; interim, quod scimus, in ciuitate notissima et eminentissima Carthagine Africae Gaudentius et Iouius comites imperatoris Honorii quarto decimo Kalendas Aprilis falsorum deorum templa euerterunt et simulacra fregerunt" [podkr. - M.W.].

${ }^{32}$ Por. CTh XVI 10, 17, ed. Mommsen - Meyer, vol. 1, pars 2, s. 902. Podobne rozporządzenia, jak te wysłane do Afryki, przekazano również Makrobiuszowi, wikariuszowi Hiszpanii (CTh XVI 10, 15, ed. Mommsen - Meyer, vol. 1, pars 2, s. 901), zakazując szkodliwego i bezmyślnego niszczenia budynków związanych dawniej z kultem pogańskim. Wiele racji ma Monika Ożóg (Kościót starożytny wobec światyń oraz posagów bóstw, Kraków 2009, 117), która podkreśla, że w treści dekretów wydawanych przez Honoriusza (Stilichona) widać troskę o to, by nie niszczono substancji architektonicznej, jeżeli w budynkach dawnych świątyń pogańskich nie ma „rzeczy niedozwolonych". Chodziło tutaj o posagi bogów i ołtarze, które mogły i miały być niszczone bezwzględnie. Zapewne za próbami powstrzymania dewastacji budynków dawnych świątyń stał Stilichon, uważający prawdopodobnie tego typu liberalne posunięcia za potencjalny atut (trzymany w rękawie), którym mógł się w odpowiednim momencie posłużyć w dyskusji z kręgami propogańskimi w senacie, przedstawiając je jako przykład swej empatii i dobrej woli.

${ }^{33}$ Oto kilka zaledwie przykładów tego typu rozporządzeń prawnych: CTh XVI 5, 35, 37, 38, 39 i 40, ed. Mommsen - Meyer, vol. 1, pars 2, s. 866-868.

${ }^{34}$ Za przyjęciem tezy, że przywrócenie posągu bogini Wiktorii w senacie nastąpiło w początkowej fazie rządów Stilichona (zapewne między rokiem 399 a 400) optuje Tido Janßen (Das weströmische Reich vom Tode des Theodosius bis zur Ermordung Stilichos, s. 107, nota 8 i s. 121 nota 99), idąc za strofami Klaudiana i powołując się na ustalenia André Chastagnola (La préfecture urbaine à Rome sous le Bas-Empire, Publications de la Faculté des Lettres et Sciences Humaines d'Alger, Paris 1960, 165, nota 5). Natomiast Monika Ożóg (Kościót starożytny wobec światyń oraz posagów bóstw, s. 119) przesuwa to wydarzenie na okres późniejszy, kiedy to dwór Honoriusza na skutek najazdu Alaryka opuścił Mediolan i przeniósł się do Rawenny.

${ }^{35}$ Por. Wilczyński, Germanie w stużbie zachodniorzymskiej w V w. n.e., s. 204 (ze wskazaniem źródeł w nocie 17). 
okresie budowania dobrych stosunków Stilichona z senatem Eucheriusz był kilkuletnim dzieckiem i w żadnym wypadku nie liczyły się jego przekonania religijne, a potem, gdy był już młodzieńcem, sytuacja zmieniła się na tyle, że pogłoski o jego pogańskich skłonnościach jedynie szkodziły ojcu.

Wszelkie manewry wykonywane pomiędzy zwolennikami pogaństwa a chrześcijanami były częścią większej gry politycznej mającej zapewnić Stilichonowi dobre stosunki z senatem i byłymi stronnikami Eugeniusza. Znamienne jest, że opiekun cesarza Honoriusza nie dopuszczał do szeroko zakrojonych konfiskat majątków stronników uzurpatora, mimo bardzo trudnej sytuacji finansowej w początkowej fazie jego rządów. Bezpośrednio po śmierci Teodozjusza Stilichon musiał sprostać niełatwemu zadaniu utrzymania praktycznie dwóch armii comitatenses stacjonujących w Italii - wschodniej i zachodniej. Dodatkową trudnością były deficyty w zaopatrzeniu Miasta w zboże. W zasadzie przed buntem Gildona niedostatki aprowizacyjne Miasta były stałym przedmiotem troski władz Zachodu ${ }^{36}$. Prostym a zarazem najgorszym rozwiązaniem byłoby zasilenie skarbu majątkami rodzin senatorskich wspierających Eugeniusza i ogólne podniesienie podatków. Jednak Stilichon pragnął przede wszystkim pojednania z italską arystokracją, a każde z podanych rozwiązań wykopałoby przepaść między nowa, przybyłą ze wschodu ekipą rządząca, a mimo wszystko bardzo wpływową warstwą italskich possessores. Ostatecznie bardzo oględna polityka wobec senatu znalazła wyraz w ustaleniu wyważonych podatków. Członkowie stanu senatorskiego zostali zobowiązani do wpłacania z początkiem każdego roku 72 solidów nowego podatku ${ }^{37}$. Taka kwota, za którą można było utrzymać kilku rekrutów, nie była dla senatorów znaczącym wydatkiem, a zatem nowy podatek nie nosił znamion represji. Część posiadaczy ziemskich skorzystała także na kasacji zaległości podatkowych w Kampanii ${ }^{38}$. Ze swej strony zachodniorzymska elita senatorska wydawała się doceniać takt nowej władzy, na co wskazuje chyba najbardziej gotowość senatorów do dwukrotnej dobrowolnej dotacji na rzecz poprawy zaopatrzenia Miasta wypłaconej w początku 396 roku $^{39}$. W pewnym sensie bunt Gildona był z politycznego punktu widzenia prezentem dla Stilichona, bowiem utrata Afryki była dla senatorów zachodnich niewyobrażalną katastrofą, a jego działania zapobiegły temu nieszczęściu. Senat wyraził zatem Stilichonowi swą wdzięczność, czego dowodem jest wyżej cytowana

${ }^{36}$ Szerzej na ten temat pisze cytowany już wyżej Tido Janßen (Das weströmische Reich vom Tode des Theodosius bis zur Ermordung Stilichos, s. 73-76).

${ }^{37}$ Por. CTh VI 1, 16, ed. Mommsen - Meyer, vol. 1, pars 2, s. 245.

${ }^{38}$ Por. tamże XI 28, 2, ed. Mommsen - Meyer, vol. 1, pars 2, s. 617. Trudno nie zauważyć, że świadomie lub nie był Stilichon pojętnym naśladowcą Juliana Apostaty, który kasując nawis zaległych świadczeń podatkowych w Galii zachęcił do bieżącego, regularnego płacenia podatków z bezdyskusyjną korzyścią dla skarbu.

${ }^{39}$ Por. Janßen, Das weströmische Reich vom Tode des Theodosius bis zur Ermordung Stilichos, s. 74-75. 
inskrypcja ${ }^{40}$. Znamienne jest też, że po kampanii afrykańskiej przyszedł czas na przekazanie pewnych urzędów dawnym oponentom Teodozjusza lub ich rodzinom, czego dobrym przykładem jest powołanie Nikomacha Flawiana (383-432) na urząd prefekta Miasta ${ }^{41}$. Te kilka podanych wyżej przykładów ukazuje wolę pojednania ze strony Stilichona, któremu udało się, przynajmniej do przełomu roku 404/405, utrzymywać poprawne, a nawet dobre stosunki z elitą senatorską.

Ad. 4. Semibarbarus Stilicho i pochodzący z Cauca w Hiszpanii Teodozjusz Wielki rozumieli bardzo dobrze procesy zachodzące nad granicami rzymskimi na Dunaju i Renie. Zdawali sobie również sprawę z tego, że zatrzymanie migracji plemion barbarzyńskich, a tym bardziej zniszczenie tych plemion, przekracza możliwości mobilizacyjne i finansowe imperium. Nie było też powodu, aby plemiona te niszczyć. Długotrwały ich pobyt w szerokiej strefie limesu, pojmowanego nie jako linia graniczna, lecz jako sięgający czasem daleko w głąb barbaricum obszar przenikania wpływów politycznych, gospodarczych i kulturowych, powodował, że nie byli to najeźdźcy w rodzaju dawnych Cymbrów i Teutonów a przybysze, których można było wykorzystywać dla wzmocnienia siły militarnej cesarstwa. Wprawdzie nieudana próba za panowania Walensa (ok. 328 - 9 VIII 378, cesarz od 28 III 364) zakończona tragedią pod Adrianopolem (9 VIII 378) mogła zniechęcać, jednak Teodozjuszowe rozwiązanie kwestii gockiej wskazywało na możliwość współpracy gwarantowanej przez kontrolę nad barbarzyńcami i umiejętnie zawierane foedera. Aż do feralnego roku 406 Stilichonowi udawało się prowadzić bardzo skuteczną politykę wobec barbarzyńców. Jego zaangażowanie militarne w obronę Bałkanów przed rabunkami Wizygotów, jego skuteczna polityka sojuszy z plemionami frankońskimi, zabezpieczająca granicę na Renie ${ }^{42}$, czy powstrzymanie Alaryka pod Pollentią zjednywały mu wdzięczność i opinię skutecznego, zwycięskiego wodza, choć trudno szukać w karierze Stilichona olśniewających przykładów militarnego geniuszu. Kilkakrotnie dał dowód, że jest wierny zasadzie „wykorzystać, nie niszczyć”, dwukrotnie (w roku 391 i 402) powstrzymując się przed pokusą unicestwienia zdesperowanych, a więc niebezpiecznych, Wizygotów. Ostatecznie zaś ujarzmił wroga i zmusił do powrotu na przyznane wcześniej ziemie, oszczędzając w ten sposób barbarzyńców z myślą o późniejszym wykorzystaniu ich dla dobra cesarstwa. Próba wykorzystania Alaryka i jego wojowników w wewnętrznym konflikcie, jak też rozpaczliwe poszukiwanie możliwości „zagospodarowania” króla Wizygotów wobec uzurpacji Konstantyna

\footnotetext{
${ }^{40}$ Por. nota 3.

${ }^{41}$ Obszerniej na ten temat wypowiada się Meaghan McEvoy (Child Emperor Rule in the Late Roman West AD 367-455, s. 148).

${ }^{42}$ Por. Claudianus, De VI consulatu Honorii 439-459, ed. Birt, MGH Auctores Antiquissimi X 251; tenże, De consulatu Stilichonis I 189-245, MGH Auctores Antiquissimi X 196-198; tamże II 237-245, MGH Auctores Antiquissimi X 211.
} 
III († przed 18 IX 411) świadczą o tym, że Stilichon nie tracił nadziei na skuteczne spożytkowanie sił sojuszniczych oddziałów barbarzyńców.

W pierwszych latach V w. kariera Stilichona osiagnęła swoje apogeum. Znajdował się bowiem wówczas na najwyższym szczeblu administracyjno-wojskowej struktury cesarstwa zachodniego, stojąc obok tronu cesarskiego jako podwójny powinowaty cesarza Honoriusza (przez Serenę i przez Marię), najwyższy dowódca ufającej mu armii i najważniejszy urzędnik imperium, darzony ostrożnym zaufaniem senatu. Moment przełomowy w jego świetnej karierze nastąpił wprawdzie w roku 408, ale zapowiedzi przyszłej drogi w otchłań datować można na lata 404/405. Przyczyn tego kryzysu należy doszukiwać się na tych samych polach działalności, które omówiono przy analizie drogi Flawiusza Stilichona na szczyty władzy:

Ad. 1. Wydawać się mogło, że mimo osiąnnięcia przez Honoriusza wieku 20 lat w roku 404, roku piastowania przez cesarza jego szóstego już konsulatu, pozycja Stilichona jako opiekuna cesarza pozostawała niezachwiana. Honoriusz, urażony postawą Konstantynopola wobec jego interwencji w obronie zwolenników Jana Chryzostoma (ok. 350 - 14 IX 407), gotów był ściśle współpracować ze Stilichonem w celu zagarnięcia całości Illyricum. Istniały jednak okoliczności psujące harmonię rodzinną. Na pewno jedną z nich był brak potomka z małżeństwa z Marią. Z kolei fatalne dla cesarstwa zachodniego wydarzenia lat 406-408 spowodowały zapewne wzrost nieufności cesarza w stosunku do teścia. Inwazja barbarzyńska na Galię i brak szybkich sukcesów w zwalczaniu uzurpacji Konstantyna III zostały wykorzystane przez ludzi niechętnych Stilichonowi dla osłabienia zaufania cesarza, a następnie do przekonania go, że Stilichon dąży do objęcia pełni władzy w imperium. Stronnictwo wrogie rządcy Zachodu, na czele którego stał Olimpiusz († 409/410) tworzyło skutecznie „,czarną legendę” Stilichona, przebiegłego Wandala chcącego przejąć władzę dla siebie lub dla swego syna Eucheriusza, a to oznaczało zamach stanu i pozbycie się prawowitego cesarza, czyli Honoriusza. Filostorgiusz (368 - ok. 439) zarzucał Stilichonowi wywołanie bezpłodności Honoriusza za pomocą trucizny w celu zapewnienia purpury swojemu syno$\mathrm{wi}^{43}$. W tym samym celu miał on także spowodować najazd barbarzyńców na Galię $^{44}$. Orozjusz (375 - przed 418) natomiast z goryczą oskarżał go o to, że, aby swemu synowi zapewnić panowanie, nie zawahał się przed przelaniem

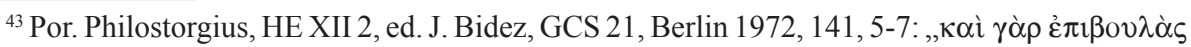

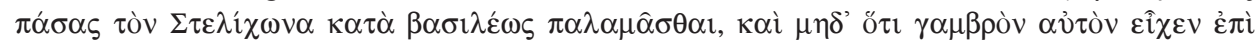

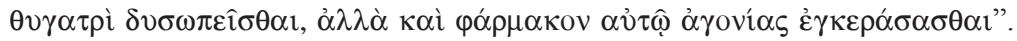

${ }^{44}$ Por. Jordanes, Romana 322, ed. Th. Mommsen: MGH Auctores Antiquissimi V/1 41: ,spraeto Honorio regnumque eius inhians Alanorum Suavorum Vandalorumque gentes donis pecuniisque inlectas contra regnum Honorii excitavit, Eucherium filium suum paganum et Christianis insidias molientem cupiens Caesarem ordinare". Identyczną informację podaje Marcellinus Comes (Chroni$c a$ a. 408, 1, MGH Auctores Antiquissimi XI 69). 
krwi całego, jak to określił, rodzaju ludzkiego ${ }^{45}$. Te opinie wyrażane ex post ukazują jak skutecznie udało się przekonać dwór, cesarza i opinię publiczną o rzekomych knowaniach Stilichona. Pogarszające się relacje rodzinne dodatkowo popsuły dwa zgony. Śmierć Arkadiusza (1 V 408) rozbudziła bowiem w Honoriuszu chęć objęcia opieką osieroconego bratanka, Teodozjusza II (10 IV 401 - 28 VII 450, cesarz od 1 V 408). Stilichon odwiódł go od tych zamiarów z najwyższym trudem, sam podejmując się udać nad Bosfor i w imieniu Honoriusza otoczyć opieką Teodozjusza $\mathrm{II}^{46}$. Honoriusz uległ po raz ostatni, ale gotowość Stilichona do przejęcia rządów na Wschodzie musiała w zatrutym już oszczerstwami umyśle cesarza budzić jak najgorsze podejrzenia. Kolejnym ogniwem w rodzinnym łańcuchu powiązań, które zawiodło, była żona Stilichona, Serena, która zaszkodziła mężowi swoim zaangażowaniem w sprawę Melanii Młodszej (383 - 31 XII 439) 47 a po śmierci Marii zdecydowanie sprzeciwiała się wydaniu drugiej ich córki, Thermantii, za Honoriusza. Nie znamy powodu jej sprzeciwu. Może chodziło o rzeczywistą impotencję Honoriusza, a może przewidując już upadek męża chciała ratować siebie i córkę. Także w rozgrywce między Stilichonem a cesarzem o kontrolę nad armią działała na niekorzyść męża ${ }^{48}$. Ostatecznie w chwili próby, związki rodzinne $\mathrm{z}$ domem cesarskim nie pomogły wodzowi, a raczej mu szkodziły.

Ad. 2. Aż do końca swojej kariery Stilichon wzmacniał armię jako najistotniejszy element swojej potęgi. Po raz ostatni planował jej użycie jako instrumentu nacisku w 405 r., kiedy podjęto realne przygotowania do zbrojnej interwencji na Wschodzie, angażując w plan Wizygotów Alaryka i wojska cesarskie $^{49}$. Po raz ostatni święcił triumf militarny, gdy pokonał Radagaisa, później jednak opuściło go powodzenie wojenne. Zdecydowanie gwoździem do trumny Stilichona-polityka i Stilichona-wodza była inwazja barbarzyńców na Galię. Wprawdzie w zaistniałej wówczas sytuacji przydatne okazały się jego frankońskie sojusze, ale mimo to nie udało się zatrzymać inwazji ${ }^{50}$. Jednak

${ }^{45}$ Por. Orosius, Historiae adversum paganos VII 38, 5, CSEL 5, 544, 6-7: „ut unum puerum purpura indueret, totius generis humani sanguinem dedidit".

${ }^{46}$ Zosimos (Historia Nova V 31, 4-5, ed. Mendelssohn, s. 256) dokładnie przekazał argumenty Stilichona, który straszył Honoriusza, że jego nieobecność w Italii wykorzysta uzurpator Konstantyn III. Groził też łupieżczym najazdem Alaryka i jego Gotów. Radził więc cesarzowi zostać na czele sił Italii na miejscu, zaś Alaryka skierować przeciw uzurpatorowi, a jego samego wyposażonego w pełnomocnictwa Honoriusza posłać do Konstantynopola. Por też Hughes, Stilicho, s. 205; Janßen, Das weströmische Reich vom Tode des Theodosius bis zur Ermordung Stilichos, s. 240.

${ }^{47}$ Por. punkt ad. 3.

${ }^{48}$ Por. Wilczyński, Germanie w stużbie zachodniorzymskiej w V w. n.e., s. 379-380.

${ }^{49}$ Por. tamże, s. 141 i 366.

${ }^{50}$ O przedarciu się barbarzyńców, głównie Wandalów, Alanów i Swebów, przez granicę na Renie napisano wiele. Dla orientacji Czytelnika tylko kilka najnowszych publikacji: M. Kulikowski, Barbarians in Gaul, Usurpers in Britain, „Britania” 31 (2000) 325-331; Janßen, Das weströmische Reich vom Tode des Theodosius bis zur Ermordung Stilichos, s. 202-204; Strzelczyk, Wandalowie 
cierpienia mieszkańców Galii w mniejszym stopniu napełniały Honoriusza niepokojem niż uzurpacja Konstantyna III, który o wiele skuteczniej niż legalny cesarz powstrzymywał gwałty najeźdźców w prowincjach galijskich ${ }^{51}$. Wobec niemożności szybkiego rozwiązania problemu barbarzyńców i uzurpatora w Galii, autorytet Stilichona osłabł zarówno w oczach cesarza, jak i w armii, co ułatwiło wykorzystanie jednostek italskich do zainscenizowania buntu $\mathrm{W}$ garnizonie $\mathrm{w}$ Ticinum ${ }^{52}$. W zamieszkach zabito kilku współpracowników Stilichona, a Olimpiusz mobilizował armię do obrony cesarza przed domniemanymi, morderczymi planami Stilichona. Ten ostatni początkowo wziął bunt za rozruchy antycesarskie i chciał na czele oddziałów barbarzyńskich zapewnić Honoriuszowi bezpieczeństwo. Kiedy jednak dowiedział się, że cesarz jest bezpieczny, a bunt wymierzony jest w niego samego, zaniechał działań przeciw zbuntowanym jednostkom italskim. Dysponując jednostkami wojsk barbarzyńskich w służbie cesarskiej i możliwym wsparciem ze strony stacjonującego w Emonie (Ljublianie) Alaryka, nie zdecydował się na podjęcie rzuconego mu wezwania, by nie niszczyć odbudowanej przez siebie italskiej armii, mimo że ta zwróciła się przeciw niemu. Nie skorzystał też z pomocy wiernych sobie oddziałów, aby uniknąć egzekucji w Rawennie ${ }^{53}$. Jego bierność i brak chęci walki o życie były dla barbarzyńskich żołnierzy i dowódców niezrozumiałe i spowodowały utratę wsparcia ze strony tej właśnie, wiernej mu części armii ${ }^{54}$.

i ich afrykańskie państwo, s. 81-89; Wilczyński, Zagraniczna i wewnętrzna polityka afrykańskiego państwa Wandalów, s. 15-19; tenże, Gejzeryk i „,czwarta wojna punicka”, s. 43-48; M. Pawlak, Konflikty Rzymian z barbarzyńcami nad Renem w latach 365-425, w: Barbarzyńcy u bram imperium, red. S. Turlej, Kraków 2007, 79-87; tenże, Rzymski zachód w latach 395-493, w: Świat rzymski w V wieku, red. R. Kosiński - K. Twardowska, Kraków 2010, 27; Castritius, Die Vandalen. Etappen einer Spurensuche, s. 46-57; P. Heather, Why Did the Barbarian Cross the Rhine?, „Journal of Late Antiquity" 2 (2009) 3-29; Hughes, Stilicho, s. 177-184; A. Merrills - R. Miles, The Vandals, Chichester 2010, 35-41; K. Vössing, Das Königreich der Vandalen. Geiserichs Herrschaft und das Imperium Romanum, Darmstadt 2014, 18-20; Y. Modéran, Les Vandales et l'Empire Romain, Arles 2014, 63-76; Steinacher, Die Vandalen, s. 49-57; McEvoy, Child Emperor Rule in the Late Roman West AD 367-455, s. 176-177.

${ }^{51}$ Świadectwa Zosimosa (Historia Nova VI 2, 2-3, ed. Mendelssohn, s. 283; tamże VI 3,1-3, ed. Mendelssohn, s. 284-285) nie pozostawiają co do tego wątpliwości. Na temat uzurpacji Konstantyna por. Kulikowski, Barbarians in Gaul, Usurpers in Britain, s. 332-341.

${ }^{52}$ Por. Zosimus, Historia Nova V 32 1-7, ed. Mendelssohn, s. 257-259.

${ }^{53}$ Por. tamże V 34, 4-5, ed. Mendelssohn, s. 260-261 - po wywabieniu Stilichona z azylu kościelnego, gdy prowadzono go na śmierć, żołnierze barbarzyńscy i jego domownicy chcieli go uwolnić, jednak on sam ich uspokoił i odwiódł od zamiaru buntu, rezygnując tym samym z możliwości uratowania życia.

${ }^{54}$ Rozpaczliwe próby uwolnienia wodza, podejmowane tuż przed egzekucją nie były jedynymi. Jest możliwe, że nocny atak Sarusa na huńskich buccellarii Stilichona był próbą powstrzymania wodza od samobójczej decyzji udania się do Rawenny i zmuszenia go do tego, aby stanął na czele barbarzyńskich foederati i rozprawił się z Olimpiuszem i armią italską z Ticinum. Nocny napad wiernego dotąd Stilichonowi Sarusa opisał Zosimos (Historia Nova V 34, 1, ed. Mendelssohn, s. 260), ale relacja ta nie pozwala na absolutnie pewne określenie motywów kierujących Sarusem. 
Wywabiony podle z azylu kościelnego oddał głowę pod miecz 22 lub 23 sierpnia $408 \mathrm{roku}^{55}$.

Ad. 3. Zazwyczaj za powód odwrócenia się arystokracji italskiej od Stilichona uważa się wymuszenie na senacie przez magistra militum przyznania Wizygotom wielkich subsydiów, których żądał Alaryk za długotrwałą bezczynność w oczekiwaniu na wspólną akcję, mającą na celu zajęcie Illyricum. Jak wspomniano już powyżej król Wizygotów miał wesprzeć jako zachodniorzymski magister militum kontyngent armii Zachodu, mający odebrać Konstantynopolowi całość spornego terytorium Illyricum. Plany te nie zostały nigdy zrealizowane z powodu najazdu Radagaisa, inwazji barbarzyńców w Galii i uzurpacji Konstantyna. Alaryk długo oczekiwał w Epirze na rozkaz ataku, cierpiąc wskutek braku zaopatrzenia dla swoich wojsk ${ }^{56}$. Nie doczekawszy się ruszył na Zachód i stanął obozem u bram Italii w Emonie, skąd wysłał do Rawenny poselstwo z żądaniem wypłaty rekompensaty za bezczynne oczekiwanie w Epirze ${ }^{57}$. Stilichon, by uzyskać zgodę senatorów na wypłatę czterech tysięcy funtów złota dla barbarzyńcy, musiał przedstawić im wszelkie, dotychczas tajne plany, dotyczące podboju Illyricum (a więc de facto wojny

\footnotetext{
Dodać należy, że już wcześniej Stilichon nie zgodził się na atak wojsk barbarzyńskich na armię stacjonującą w Ticinum (tamże V 33, 2, ed. Mendelssohn, s. 259-260).

${ }^{55}$ Egzekucja jest datowana przez Zosimosa (Historia Nova V 34, 7, ed. Mendelssohn, s. 261) na 10 kalendy września, czyli na 23 VIII. Natomiast Excerpta Sangallensia 539, ed. Th. Mommsen, MGH Auctores Antiquissimi IX, Berolini 1892, 300 oraz Additamenta ad Prosperum Havniensia a. 408, 3, ed. Th. Mommsen, MGH Auctores Antiquissimi IX 300 przesuwają datę egzekucji o dzień wcześniej. Prócz nich bez datowania wydarzenia relacjonują je: Orosius, Historiae adversum paganos VII 38, 5, CSEL 5, 544, 3-7; Philostorgius, HE XI 3, GCS 21, 135, 13-15 (pierwszy schemat śmierci Stilichona); tamże XII 1, GCS 21, 140, 1-7 (drugi schemat śmierci Stilichona); tamże XII 1, GCS 21, 140, 8-13 (trzeci schemat śmierci Stilichona); tamże XII 3, GCS 21, 141, 13 (krótka, ogólnikowa wzmianka o jego śmierci); Sozomenus, HE IX 4, 8, ed. J. Bidez, GCS 50, Berlin 1960, 396, 13-17; Jordanes, Getica 154, MGH Auctores Antiquissimi V/1 98; tenże, Romana 322, MGH Auctores Antiquissimi V/1 41; Marcellinus Comes, Chronica a. 408, 1, MGH Auctores Antiquissimi XI 69; Paulus Diaconus, Historia Romana XII, 16, rec. H. Droysen, MGH Auctores Antiquissimi XI 195.

${ }^{56}$ Istnienie wspólnych planów ataku na Illyricum potwierdza Olympiodorus (Historiarum librorum XXII fragmenta 5, 2, ed. Blockley, s. 156). W literaturze fachowej temat ostatecznego upadku i śmierci Stilichona analizowali: Mazzarino, Stilicone. La crisi imperiale dopo Teodosio, s. 280-283; Nischer-Falkenhof, Stilicho, s. 139-142; Demougeot, De l'unité à la division de l'empire romain: 395-410, s. 397-402; K. Zakrzewski, U schytku świata antycznego, Warszawa 1964, 110-114; Schwarcz, Reichsangehörige Personen gotischer Herkunft, s. 197-198; Wolfram, Das Reich und die Germanen. Zwischen, s. 156; Wilczyński, Germanie w stużbie zachodniorzymskiej w V w. n.e., s. 382-387; Janßen, Das weströmische Reich vom Tode des Theodosius bis zur Ermordung Stilichos, s. 243-244; Heather, Upadek Cesarstwa Rzymskiego, s. 260-263; Hughes, Stilicho, s. 209; Pawlak, Rzymski zachód w latach 395-493, s. 28-30; McEvoy, Child Emperor Rule in the Late Roman West AD 367-455, s. 183-186; M. Kulikowski, Wojny Rzymu z Gotami od III wieku do Alaryka, Oświęcim 2015, 137; Ch. Delaplace, La fin del'Empire romain d'Occident. Rome et les Wisigoths de 382 à 531, Collection „Histoire”, Rennes 2015, 138.

${ }^{57}$ Por. Zosimus, Historia Nova V 29, 1 i 4-5, ed. Mendelssohn, s. 251-253.
} 
rzymsko-rzymskiej). To nie spotkało się z uznaniem patrum conscriptorum. Mimo to Stilichon ostatecznie zmusił senat do niechętnej zgody na wypłacenie dotacji dla Alaryka, która przez większość senatu postrzegana była po prostu jako haracz dla barbarzyńcy ${ }^{58}$. Na pewno tajne plany przeciw wschodniemu cesarstwu oraz ogromny ciężar wymuszonej przez barbarzyńcę kwoty poważnie nadszarpnęły zaufanie senatu do Stilichona. Jednak nie był to jedyny zgrzyt psujący stosunki magistra militum z italską arystokracją. Nadmierna aktywność Honoriusza w ramach polityki religijnej przejawiana w 407 r. nie była prawdopodobnie planową akcją, godzącą w delikatną równowagę między poganami a chrześcijanami osiagnnięta przez Stilichona, lecz raczej poszukiwaniem pomocy Boskiej w trudnej dla imperium sytuacji, ale na pewno szkodziła porozumieniu z pogańskimi kręgami senatu. Obok represji przeciw heretykom wznowiono bowiem energiczne działania, zmierzające do ostatecznego wykorzenienia pogaństwa ${ }^{59}$, a to psuło cichą ugodę między magistrem militum a częścią senatu. Inna jeszcze, pozornie drobna sprawa o podłożu religijnym zniechęciła wszystkich, bez względu na wyznanie, italskich possessores. Jeszcze w roku 404, czyli w okresie, gdy pozycja Stilichona wydawała się niezachwiana, nastapił z winy Sereny incydent na pewno brzemienny dla dalszych stosunków Stilichona z senatem. Oto młoda Rzymianka Melania (św. Melania Młodsza) wraz ze swym małżonkiem Pinianusem (ok. 381 - 420 lub 432) postanowili realizować ideał chrześcijańskiego ubóstwa i rozdać cały swój majątek. Oboje należeli do najwyższych kręgów rzymskiej elity senatorskiej. Tymczasem w Wiecznym Mieście przeciwni każdemu umniejszaniu stanu posiadania rodów senatorskich byli tak chrześcijańscy jak i pogańscy senatorowie. Nawet babka pobożnej dwudziestolatki, będąca dla niej wzorem życia zgodnego z radami ewangelicznymi, porzuciła swe życie anachoretki żyjącej w ubóstwie w Palestynie i przybyła do Italii, aby wyperswadować wnuczce jej zamiar. Natomiast niewolnicy zbożnej pary byli na granicy buntu, obawiając się zmiany właścicieli. Melania Młodsza w desperacji zwróciła się o pomoc do Sereny, a ta przekonała Honoriusza, by zniósł kuratelę rodzin nad małżonka$\mathrm{mi}$, a namiestnikom prowincji nakazał pomoc w rozsprzedaniu ich ogromnego

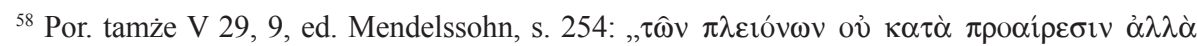

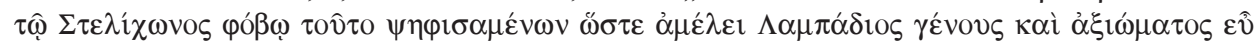

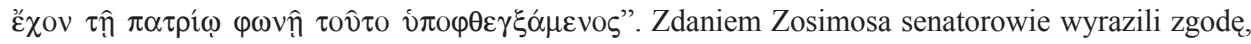
bo bali się Stilichona, a jedynie senator Lampadiusz miał odwagę jawnie, choć cicho, nazwać układ z Gotami paktem poddania: „non est ista pax sed pactio servitutis”. Ciekawie komentował to J.F. Matthews (Olympiodorus of Thebes and the History of the West (A.D. 407-425), JRS 60:1970, 86-87).

${ }^{59}$ Większość edyktów antyheretyckich wydanych w roku 407 i 408 (CTh XVI 5, 39-56, ed. Mommsen - Meyer, vol. 1, pars 2, s. 867-875) dotyczyła przede wszystkim donatystów, manichejczyków i pryscylian, jednak niektóre akty prawne przypominały dawne edykty antypogańskie, czy wprost wymieniały także wyznawców dawnej religii, por. CTh XVI 5, 41, 42, 43, 46, ed. Mommsen - Meyer, vol. 1, pars 2, s. 868-875. Poza tym chętnie sięgano do dość ogólnego potępienia wszystkich „wrogów Kościoła katolickiego”, do których bez wątpienia zaliczano i pogan. 
majątku ${ }^{60}$. Choć Serena działała zapewne bez porozumienia ze Stilichonem, jednak niezadowolenie elity senatorskiej zaszkodziło w przyszłości głównie jemu $^{61}$. W decydującym więc momencie kryzysu 408 r. magister militum nie mógł liczyć na przychylność italskiej arystokracji, o którą zabiegał usilnie od momentu przybycia na Zachód.

Ad. 4. Paradoksalnie najbardziej trwałym elementem, na którym ewentualnie mógł się oprzeć zagrożony knowaniami Olimpiusza i niełaską cesarską Stilichon, pozostali barbarzyńcy. Nie zdradziły go sojusznicze plemiona frankońskie, które na przedpolu reńskiego limesu złożyły daninę krwi, choć nie powstrzymały najazdu plemion barbarzyńskich na Galię. Do końca także pozostali mu wierni barbarzyńscy foederati, którzy odstapili go dopiero skutkiem niezrozumiałej dla nich niechęci wodza do podjęcia realnej obrony swej pozycji i życia, w której to walce chcieli stanąć po jego stronie ${ }^{62}$. Pytanie o to, jaką pozycję w zaistniałym konflikcie zająć mógł Alaryk, pozostanie otwarte. Tradycyjnie postrzega się Stilichona i króla Wizygotów jako konkurentów i wrogów, jednak czy dynamicznie rozwijająca się i zmienna sytuacja nie mogła tego zmienić? Istnieje w relacji Zosimosa ciekawa wzmianka, odnoszą-

${ }^{60}$ [Gerontius], Vita sanctae Melaniae Iunioris 9-13, ed. D. Gorce, SCh 90, Paris 1962, 142-154, tłum. K. Wojtalik: Żywot Melanii Młodszej, Warszawa 2016, 25-30. „Afera Melanii” i postępująca mniej więcej równolegle akcja przekazywania urzędów centralnych i lokalnych zdeklarowanym zwolennikom chrześcijaństwa źle służyły pojednaniu Stilichona z senatem. Por. też P.R.L. Brown Aspects of the Christianization of the Roman Aristocracy, JRS 51 (1961) 9; Janßen, Das weströmische Reich vom Tode des Theodosius bis zur Ermordung Stilichos, s. 163-165; P. Szczur, Melania Młodsza, EK XII 488; Hughes, Stilicho, s. 156-157; B. Witos, Osoba św. Melanii Młodszej w świetle „Vita Sanctae Melaniae Senatricis Romae” autorstwa Geroncjusza, PS 19 (2015) nr 3(40), 16 - w przypadku tej ostatniej publikacji trudno zgodzić się z prezentowanym tam twierdzeniem, że Melania Młodsza była przyjaciółką Sereny. Cały bowiem opis spotkania żony Stilichona i młodej świętej przeczy takiemu założeniu dokonanemu przez Autorkę artykułu. Natomiast ciekawostką jest, że tak w wersji greckiej jak i łacińskiej żywota św. Melanii Młodszej Serena, żona Stilichona, nazywana jest cesarzową ( $\beta \alpha \sigma i \lambda \iota \sigma \sigma \alpha$, regina). Zapewne nie chodzi tutaj ani o uznanie, czyli podkreślenie, że de facto pełniła funkcję cesarzowej, ani tym bardziej o ukazanie pozycji i wpływów Stilichona. Bardzo możliwe, że autor chciał w ten sposób zwrócić uwagę na jej przynależność do najbliższej rodziny cesarza, ponieważ, jak wiadomo, była ona zarówno teściową Honoriusza jak i bratanicą Teodozjusza I Wielkiego.

${ }^{61}$ Chodzi tutaj o tzw. bliższą perspektywę, ponieważ w dalszej upadek Stilichona pociągnął za sobą nie tylko śmierć jego syna Eucheriusza, lecz także (niedługo potem) i samej Sereny, która została skazana na śmierć przez uduszenie wyrokiem senatu, podejrzewającego, że jest ona skrytą sojuszniczką Alaryka, oblegającego po raz pierwszy Miasto w roku 408. Zosimos (Historia Nova V 38, 4, ed. Mendelssohn, 265-266) opowiadający tę historię twierdzi, że była to kara za dawne świętokradcze zagarnięcie naszyjnika z posągu bogini Rei, jednak na pewno zaważyły dawne uprzedzenia i rozbudzony przez pomówienia irracjonalny strach przed rzekomymi knowaniami Stilichona i jego rodziny.

${ }^{62}$ Philostorgius (HE XII 3, GCS 21, 141, 13-14) twierdzi nawet, że po śmierci Stilichona wojska barbarzyńskie ochraniały Eucheriusza i plądrowały w ramach zemsty okolice Rzymu. Pytanie tylko, czy można temu świadectwu wierzyć? 
ca się do czasu pierwszego oblężenia Rzymu. Wówczas to gnębieni głodem mieszkańcy nadtybrzańskiej metropolii zdecydowali się wyprawić do obozu Gotów poselstwo także dlatego, że nie wiedzieli, czy Miasto oblega sam Alaryk czy też „ktoś inny ze stronników Stilichona" ${ }^{63}$. Naiwnością byłoby wnioskować, że jest to ślad istniejącego sojuszu Alaryka ze Stilichonem. Może uważano, że stronnicy Stilichona przeszli na stronę króla Gotów, co zresztą było faktem, albowiem po zbrodniczym wymordowaniu na rozkaz Olimpiusza rodzin barbarzyńskich foederati dość liczna grupa wiernych dotąd Rzymowi wojsk przeszła na stronę Alaryka ${ }^{64}$. Nie wiadomo jednak nic o dowódcach, którzy wesprzeć mieli siły Wizygotów. Stilichon za swojego życia walczył z Wizygotami tylko wtedy, gdy było to konieczne. Zawsze jednak miał nadzieję, że ostatecznie uda się ich pozyskać dla dobra cesarstwa. Praktycznie od roku 404 traktował Alaryka jako oficera w służbie zachodniej i starał się wykorzystać jego lud do walki bądź z Konstantynopolem, bądź z Konstantynem III. Mógł więc sięgnąć po pomoc Alaryka w krytycznym momencie, czyniąc go swoim najbliższym politycznym sojusznikiem i kierując przeciw kamaryli Olimpiusza. Z takim wykorzystaniem barbarzyńców nie mieli problemu ani germański Rycymer († 18 VIII 472), bez skrupułów odwołujący się do pomocy Wizygotów czy Burgundów przeciw swym wrogom politycznym, ani też „ostatni Rzymianin”, Aecjusz (ok. 390 - 21 IX 454), sięgający w podobnym celu po pomoc Hunów. Stilichon zaś nawet jeżeli brał taki wariant pod uwagę, to jednak w ostatecznym rozrachunku go nie wykorzystał.

Tę ostatnią refleksję można potraktować jako swego rodzaju wstęp do poniższych wniosków końcowych. Na pytanie, dlaczego upadł Stilichon wypada grosso modo odpowiedzieć w ten sposób: ponieważ wbrew stawianym mu zarzutom nie był ani barbarzyńca, ani zdrajcą. W kilkadziesiąt lat później Rycymerowi nie drgnęła nawet ręka, gdy kreował i obalał cesarzy, wliczając $\mathrm{w}$ to jego teścia, Anthemiusza (ok. 420 - 11 VII 472). Stilichon miał analogiczne możliwości, a jednak nie sięgnął po rozwiązanie siłowe. Nie można wykluczyć, że - snując nici powinowactwa między swoją rodziną a domem Teodozjańskim - planował wielką przyszłość dla swoich potomków, ale nie za cenę podniesienia ręki na potomków Tedozjusza I Wielkiego. Gruntownie od dziecka zromanizowany mimo wszelkich ambicji rozumiał żywotne interesy imperium i starał się je jak najlepiej zabezpieczać. Najlepszym dowodem na to, że nie były mu obce archaiczne rzymskie virtutes, może być fakt, iż nie chciał ratować swego życia kosztem zniszczenia własnego dziecka, jakim była tworzona

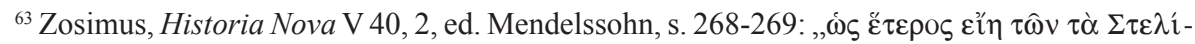

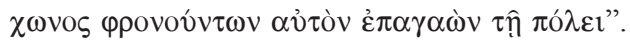

${ }^{64}$ Por. Philostorgius, HE XII 3, GCS 21, 141, 17-19. Zosimos (Historia Nova V 35, 5-6, ed. Mendelssohn, s. 262-263) szacował ich liczbę na około trzydzieści tysięcy. 
w Ticinum armia italska, nawet wtedy, gdy dziecko to w rękach Olimpiusza i jego stronnictwa okazało się Brutusem. Pewną słabością Stilichona była natomiast zdecydowanie „miękka” polityka wobec ludzi rządzących w Konstantynopolu w imieniu Arkadiusza. Co prawda dla dochowania wierności Teodozjuszowi Wielkiemu chciał tuteli nad obydwoma jego synami, ale nie za cenę konfliktu zbrojnego. Gdy zaś zdecydował się na energiczniejsze działania w roku 404, było już zbyt późno i podjęta akcja nie tylko nie przyniosła zajęcia Illyricum, ale wygenerowała dalsze problemy w postaci roszczeń Alaryka, a te $\mathrm{z}$ kolei $\mathrm{w}$ połączeniu $\mathrm{z}$ niezawinionym przez samego Stilichona zepsuciem stosunków z elitą senatorską podkopały ten istotny filar potegi opiekuna Honoriusza, tworząc sytuację korzystną dla dalszej emancypacji politycznej cesarza. Nie bez znaczenia były także niepowodzenia militarne w Galii, przy czym dla Honoriusza o wiele bardziej drażliwa była niezdolność Stilichona do natychmiastowego ukrócenia uzurpacji Konstantyna III niż gwałty zadawane galijskim Rzymianom przez barbarzyńców. W chwili próby cztery filary potęgi Flawiusza Stilichona zawiodły, a ich ukryte słabości połączone z niesprzyjającymi okolicznościami zewnętrznymi spowodowały jego upadek.

\author{
ROAD TO THE TOP AND ROAD TO THE CHASM \\ - A FEW REMARKS OF FLAVIUS STILICHO'S CAREER
}

\title{
(Summary)
}

The most important factors responsible for development of an impressive career of Flavius Stilicho were: his family ties with Theodosians' dynasty, the way he reorganized the Roman army, military victories, how he drummed up senate's support for his political aims and the balanced policy of using and stopping the barbarian tribes. Protecting emperor Honorius, cooperating simultaneously with pagan and Christian fractions in the senate, achieving military success and defending borders of the Roman Empire against barbarians raids, Stilicho de facto was reigning the state in the name of his son-in-law, Honorius. Paradoxically, the same factors contributed to the downfall of the master-in-chief in 404-408 A.D. The conflict with his wife, Serena, and his son-in-law, Honorius, the mutiny in the army called-up by the reforms of Stilicho, some disagreements with the senate caused by the case of Melania the Younger and compensation for Alaric and, at last, the invasion of barbarian tribes on Gaul in 406 A.D. destroyed the carefully built career of Flavius Stilicho. He didn't decide to keep his high rank by triggering off a civil war, what differed him clearly from his followers, Flavius Aetius and Flavius Ricimer.

Key words: Late Antiquity, the crisis of the Late Roman Empire, Stilicho, career, the Late Roman aristocracy. 
Słowa kluczowe: późny antyk, kryzys cesarstwa rzymskiego na Zachodzie, Stilichon, kariera, arystokracja późnorzymska.

\title{
BIBLIOGRAFIA
}

\author{
Źródła:
}

Additamenta ad Prosperum Havniensia, ed. Th. Mommsen, MGH Auctores Antiquissimi IX, Berolini 1892, 298-304.

Ambrosius, De obitu Theodosii, PL 16, 1385-1406.

Augustinus, De civitate Dei, rec. E. Hoffmann, vol. 1-2, CSEL 40/1-2, Pragae-Vindobonae - Lipsiae 1899-1900.

Cassiodorus Aurelius, Chronica, ed. Th. Mommsen, MGH Auctores Antiquissimi XI, Berolini 1894, 109-161.

Claudianus, De bello Pollentino sive Gothico, ed. T. Birt, MGH Auctores Antiquissimi X, Berolini 1892, 259-283.

Claudianus, De consulatu Stilichonis Libri I-III, ed. T. Birt, MGH Auctores Antiquissimi X, Berolini 1892, 189-233.

Claudianus, De III consulatu Honorii, ed. T. Birt, MGH Auctores Antiquissimi X, Berolini 1892, 140-149.

Claudianus, De VI consulatu Honorii, ed. T. Birt, MGH Auctores Antiquissimi X, Berolini 1892, 234-258.

Claudianus, In Rufinum libri I-II, ed. T. Birt, MGH Auctores AntiquissimI X, Berolini $1892,17-53$.

Claudianus, Laus Serenae, ed. T. Birt, MGH Auctores Antiquissimi X, Berolini 1892, 319-327.

Corpus Inscriptionum Latinarum, VI/1: Inscriptiones urbis Romae latinae, pars 1, coll. G. Henzen - I.B. de Rossi, ed. E. Bormann - G. Henzen, Berolini 1876.

Codex Theodosianus, w: Theodosiani libri XVI cvm Constitvtionibvs Sirmondianis et leges novellae ad Theodosianvm pertinentes, ed. Th. Mommsen - P.M. Meyer, vol. 1, pars 2: Textvs cvm apparatv, Berolini 1905, 27-906.

Eunapius Sardianus, Fragmenta historica, ed. i tłum. w: Eunapios z Sardes, Zapiski histo-

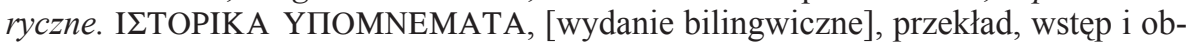
jaśnienia A. Pająkowska-Bouallegui, Christianitas Antiqua 5, Gdańsk 2013.

Excerpta Sangallensia, ed. Th. Mommsen, MGH Auctores Antiquissimi IX, Berolini 1982, 299-300 i 334-336.

[Gerontius], Vita sanctae Melaniae Iunioris, éd. D. Gorce, SCh 90, Paris 1962, thum. K. Wojtalik: Żywot Melanii Młodszej, Warszawa 2016.

IoAnnes Antiochenus, Fragmenta quae supersunt omnia, rec., Anglice vertit, indicibus instruxit S. Mariev, CFHB Series Berolinensis 47, Berolini 2008.

Jordanes, Getica (De originie actibusque Getarum), ed. Th. Mommsen, MGH Auctores Antiquissimi V/1, Berolini 1882, 53-138.

Jordanes, Romana (De summa temporum vel origine actibusque gentis Romanorum), ed. Th. Mommsen, MGH Auctores Antiquissimi V/1, Berolini 1882, 1-52.

Marcellinus Comes, Chronica, ed. Th. Mommsen, MGH Auctores Antiquissimi XI, Berolini 1894, 37-108.

OlymPIODOR, Historiarum librorum XXII fragmenta, ed. R.C. Blockley, w: The Fragmentary Classicising Historians of the Later Roman Empire. Eumapius, Olympiodorus, 
Priscus and Malchus, vol. 2: Text, Translation and Historiographical Notes, ARCA

Classical and Medieval Texts, Papers and Monographs 10, Liverpool 1983, 151-211. Orosius, Historiae adversum paganos, ed. C. Zangemeister: Orosius, Historiae adversum paganos. Liber apologeticus, CSEL 5, Wien 1882 [reprint: Hildesheim 1967], 1-564.

Paulus Diaconus, Historia Romana, rec. H. Droysen, MGH Auctores Antiquissimi II, Berolini 1879, 4-224.

Philostorgios, Historia ecclesiastica, ed. J. Bidez, GCS 21, Berlin 1972.

Prosper Tiro, Chronica, w: Prosper Tiro, Chronik. [Anonymus], Laterculus regum Vandalorum et Alanorum, ediert, übersetzt und kommentiert von M. Becker - J.-M. Kötter, Kleine und Fragmentarische Historiker der Spätantike II/G 5-6, Paderborn 2016, 64-141.

Sozomenus, Historia ecclesiastica, ed. J. Bidez, GCS 50, Berlin 1960.

Zosimus, Historia Nova, ed. L. Mendelssohn, Lipsiae 1887, łum. H. Cichocka: Zosimos, Nowa historia, Warszawa 2012.

\section{Opracowania}

Brown P.R.L., Aspects of the Christianization of the Roman Aristocracy, JRS 51 (1961) $1-11$.

Cameron A., Claudian. Poetry and Propaganda at the Court of Honorius, Oxford 1970.

Castritius H., Die Vandalen. Etappen einer Spurensuche, Stuttgart 2007.

Chastagnol A., La préfecture urbaine à Rome sous le Bas-Empire, Publications de la Faculté des Lettres et Sciences Humaines d'Alger, Paris 1960.

Demandt A., Die Spätantike. Römische Geschichte von Diocletian bis Justinian 284-565 n. Chr., München - Nördlingen 1989.

Demougeot E., De l'unité à la division de l'empire romain: 395-410, Paris 1951.

Delaplace Ch., La fin del'Empire romain d'Occident. Rome et les Wisigoths de 382 à 531 , Collection „Histoire”, Rennes 2015.

Drinkwater J.F., Constantine III (407-411) and Jovinus (411-413), „Britania” 29 (1998) 269-298.

FieBIGeR O. - SCHMidT L., Inschriftensammlung zur Geschichte der Ostgermanen, Denkschriften der Kaiserlichen Akademie der Wissenschaften in Wien. Philosophisch-historische Klasse 60/3, Wien 1917.

Halsall G., Barbarian Migrations and the Roman West, Cambridge 2007.

Hanson R.P.C., The Reaction of the Church to the Collapse of the Western Roman Empire in the Fifth Century, VigCh 26 (1972) nr 4, 272-287.

Heather P., Upadek Cesarstwa Rzymskiego, tłum. J. Szczepański, Poznań 2006.

HeAther P., Why Did the Barbarian Cross the Rhine?, ,Journal of Late Antiquity” 2 (2009) 3-29.

Hughes I., Stilicho: The Vandal Who Saved Rome, Barnsley 2010.

Janssen T., Das weströmische Reich vom Tode des Theodosius bis zur Ermordung Stilichos (395-408), Marburg 2004.

Jones A.H.M., The Prosopography of the Later Roman Empire: 260-395, Cambridge 1971.

Kampers G., Geschichte der Westgoten, Padeborn - München - Wien - Zürich 2008.

Kelly C., Neither Conquest nor Settlement: Attila's Empire and ist Impact, w: The Age of Attila, ed. M. Maas, Cambridge 2015, 193-208.

Kulikowski M., Barbarians in Gaul, Usurpers in Britain, „Britania” 31 (2000) 325-345.

Kulikowski M., Wojny Rzymu z Gotami od III wieku do Alaryka, Oświęcim 2015. 
Maenchen-Helfen O.J., Die Welt der Hunnen. Eine Analyse ihrer historischen Dimension, deutschsprachige Ausgabe besorgt von R. Göbl, Wien 1978.

Matrhews J.F., Olympiodorus of Thebes and the History of the West (A.D. 407-425), JRS 60 (1970) 79-97.

Mazzarino S., Stilicone. La crisi imperiale dopo Teodosio, Studi pubblicati dal Reale Istituto Italiano per la Storia Antica 3, Roma 1942.

McEvoy M.A., Child Emperor Rule in the Late Roman West AD 367-455, Oxford 2013.

Merrills A. - Miles R., The Vandals, Chichester 2010.

Mitchell S., A History of the Later Roman Empire (AD 284-641), Malden 2007.

Modéran Y., Les Vandales et l'Empire Romain, Éditions Errance, Arles 2014.

Nischer-Falkenhof E., Stilicho, Wien 1947.

O'FlynN J.M., Generalissimos of the Western Empire, Edmonton 1983.

OżóG M., Kościót starożytny wobec światyń oraz posagów bóstw, Kraków 2009.

Pawlak M., Konflikty Rzymian z barbarzyńcami nad Renem w latach 365-425, w: Barbarzyńcy u bram imperium, red. S. Turlej, Kraków 2010, 51-100.

Pawlak M., Rzymski zachód w latach 395-493, w: Świat rzymski w V wieku, red. R. Kosiński - K. Twardowska, Kraków 2010, 21-77.

Pfeilschifter R., Die Spätantike. Der eine Gott und die vielen Herrscher, München 2014.

Schmidt L., Die Ostgermanen, München 1941.

Schwarcz A., Reichsangehörige Personen gotischer Herkunft. Prosopographische Studien, Wien 1984 (maszynopis).

SeEck O. Flavius Stilicho, RE III A/2 (2. Reihe) 2523-2524.

Steinacher R., Die Vandalen. Aufstieg und Fall eines Barbarenreichs, Stuttgart 2016.

Stickler T., Die Hunnen, München 2007.

Straub J., Parens principum. Stilichos Reichspolitik und das Testament des Kaisers Theodosius, „La nouvelle Clio” 4 (1952) 94-115.

Strzelczyk J., Goci. Rzeczywistość i legenda, Warszawa 1984.

STRZELCZYK J., Wandalowie i ich afrykańskie państwo, Warszawa 2005.

Szczur P., Melania Młodsza, EK XII 488.

Thompson E.A., Hunowie, opr. P. Heather, thum. B. Malarecka, Warszawa 2015.

VÁRAdy L., Das letzte Jahrhundert Pannoniens. 376-476, Amsterdam 1969.

VöSsING K., Das Königreich der Vandalen. Geiserichs Herrschaft und das Imperium Romanum, Darmstadt 2014.

Wijnendaele J.W.P., Stilicho, Radagaissus, and the So-Called „Battie of Faesulae” (406 CE), ,Journal of Late Antiquity” 9 (2016) 267-284.

WiLczyŃski M. Germanie w stużbie zachodniorzymskiej w Vw. n.e. Studium historyczno-prosopograficzne, Kraków 2001.

WILCZYŃSKI M., Gejzeryk $i$ „,czwarta wojna punicka”, Oświęcim 2016.

WILCZYŃski M., Wizygoci w rejonie Bałkanów w teorii i praktyce politycznej dworów późnego cesarstwa rzymskiego, VoxP 36 (2016) t. 66, 301-325.

WILCZYŃski M., Zagraniczna i wewnętrzna polityka afrykańskiego państwa Wandalów, Kraków 1994.

Witos B., Osoba św. Melanii Młodszej w świetle „Vita Sanctae Melaniae Senatricis Romae" autorstwa Geroncjusza, PS 19 (2015) nr 3(40), 5-29.

Wolfram H., Das Reich und die Germanen. Zwischen Antike und Mittelalter, Berlin 1990.

Wolfram H., Die Goten. Von den Anfängen bis zur Mitte des sechsten Jahrhunderts. Entwurf einer historischen Ethnographie, München - Wien 1990³. 
Wood I.N., The Barbarian Invasions and First Settlements, w: The Cambridge Ancient History, vol. 13: The Late Empire, AD 337-425, ed. A. Cameron - P. Garnsey, Cambridge 1998, 516-537.

Zakrzewski K., Rzqdy i opozycja za cesarza Arkadiusza, Polska Akademia Umiejętności. Rozprawy Wydziału Historyczno-Filozoficznego II/40-2, Kraków 1927.

ZAKRZEWSKI K., U schytku świata antycznego, Warszawa 1964. 
